\title{
SURINAAMSCHE VOLKSVERTELLINGEN.
}

\author{
DOOR
}

\author{
A. P. PENARD. ${ }^{1}$ )
}

I. Ba Anansi (Broer Spin) kreeg Datra Tigri

(Dokter Tijger) mooi beet.

Eer tien tien, Eens, voor langen tijd, was de moeder van den koning ernstig ziek en de paleisdokter kon haar niet genezen. Zij nam gewillig de «leelijkste» drankjes in, maar verergerde bij den dag. Toen Zijne Majesteit dat merkte, verloor hij natuurlijk alle vertrouwen in den lijfarts en wilde de zieke door een bekwamen specialist laten onderzoeken. Hij maakte dit spoedig aan de meer ervaren geneeskundigen van zijn rijk bekend en velen boden hem hun diensten aan. 's Konings raadslieden ontrieden echter van hun kunde gebruik te maken, ja, de koning was verplicht hen heen te zenden als gepatenteerde moordenaars. Neen, hij mocht het leven van zijn innig geliefde moeder niet aan zulke lieden toevertrouwen.

De gruwelijke beschuldigingen tegen de beroemdste dokters van het land ingebracht, verwekten zulk een opschudding, dat deze geheele geschiedenis alom bekend raakte en zelfs Tata Tigri (Vader Tijger) in het bosch erover hoorde spreken. Hij kleedde zich in een zwart pakje, trok verlakte schoenen aan, zette een witten kurken helm op en ging naar het paleis. Daargekomen, diende hij zich zelf bij den koning aan als Datra Tigri. De koning vroegg zijn onderdanen om inlichtingen ook betreffende Datra Tigri, doch allen roemden zijn groote kunde uit vrees voor zijn sterke klauwen. Niet één durfde iets kwaads van hem vertellen. Zijne Majesteit gaf den grooten specialist dus verlof om de zieke vorstin te bezoeken en stelde hem vol vertrouwen aan haar voor: " hier hebt u Datra Tigri, lieve mama. Hij is onze meest be-

1) Vgl. van denzelfden schrijver het $\mathrm{XX}$ tal vertellingen in deze Bijdragen dl. 80 , blz. 325 . 
kwame inlandsche dokter, die in het bosch woont en vele geneeskrachtige kruiden kent. $\mathrm{Hij}$ is de eenige betrouwbare persoon, door wien gij u gerust kunt laten behandelen .

In 't eerst was de vorstin een beetje bang voor Datra Tigri, maar deze zeide: "vrees niet voor mij, Hooge Vrouwe. Ik ben geen God, maar zal mijn best doen u van alle pijn te verlossen, $\mathrm{U}$ behoeft mij niet voor mijn moeite te betalen. Ik zal u gratis uit den nood helpen.»

Getroffen door de woorden van Datra Tigri, stelde de oude dame zich moedig onder diens behandeling en verzocht hem vriendelijk haar afdoende te genezen. Datra Tigri wilde de vorstin meteen onderzoeken, doch niet in bijzijn van anderen. Hij kon niet ongestoord werken, als er iemand bij was. Neen, hij verlangde geen assistent. Hij verstond zijn vak uitstekend en had volstrekt geen hulp noodig.

Datra Tigri werd dus met zijn patiënte alleen gelaten en sloot de deur van het vertrek, opdat niemand hem storen zou. Daarna sprong hij op het bed, sloeg de zieke dood, scheurde haar buik open en dronk haar bloed gretig op. Hij bedekte zijn slachtofter met de dekens en sprong weer van het bed af. Toen bekeek hij zich in den spiegel, likte zijn bebloeden muil schoon en ging de kamer uit.

Nauwelijks had Datra Tigri de deur van het ziekenvertrek achter zich dichtgetrokken, of de koning trad op hem toe en vroeg ongeduldig: "hoe is 't afgeloopen, Datra? Heb je mijn moeder onderzocht? Zal zij in het leven blijven of kan je niets meer voor haar doen?»

Datra Tigri gevoelde zich niet geheel op zijn gemak, doch antwoordde uiterlijk kalm: »ik heb Uw moeder onderzocht, mijn koning, en haar tevens met succes behandeld. $Z$ ij heeft geen pijn meer en ligt onder de dekens in diepe rust. Probeer niet haar vóór het aanbreken van den dag te wekken, want dat zal U diep bedroeven."

De koning dankte Datra Tigri hartelijk voor het redden van zijn moeders leven en verzekerde hem, dat de slapende niet gestoord zou worden. Tigri keerde voldaan naar zijn hol in 't bosch terug, terwijl Zijne Majesteit zich haastte om de autoriteiten met de bekendmaking van het gebeurde te belasten. Op hun bevel marcheerden de soldaten met fakkellicht langs de straten en stelden het volk in kennis van de genezing der Dl. 82. 
vorstin door den beroemden Datra Tigri. Deze heugelijke tijding verwekte overal zoo'n groote blijdschap, dat iedereen tot laat in den nacht lustig feest vierde.

Toen de dag aanbrak, luisterde de koning voortdurend aan de deur der gesloten kamer, maar hoorde er geen geluid, zelfs niet de ademhaling van zijn moeder. Dit verontrustte hem zeer, waarom hij wilde zien of zij heusch rustig sliep. Hij opende de deur heel zachtjes en trad het vertrek binnen op zijn teenen.

Verschrikt door eenige bloedvlekken aan de dekens, trok hij deze van 't bed af en ontdekte er het lijk van de verscheurde vorstin. Toen gilde hij het uit van verdriet, waarop al de huisgenooten toesnelden, onder welke ook de lijfarts. Deze constateerde, dat de vorstin door Datra Tigri vermoord was en liet met goedkeuring van den koning dadelijk de politie roepen. Verwittigd van het gebeurde, verscheen de geheele politiemacht, aangevoerd door den commissaris, in het paleis. Na een kort onderhoud met den koning, loofde de commissaris een som gelds uit als belooning voor dengene, die Datra Tigri gevangen nam, doch niemand wilde er zijn leven aan wagen.

Doch $\mathrm{Ba}$ Anansi vreesde Datra Tigri niet en zou hem aan den koning overleveren. Daarvoor had hij slechts twee flesschen sterken spiritus noodig, alsook een grooten jutezak. Nu stelde de koning niet veel vertrouwen in Anansi, maar daar hij geen andere voor die gewaagde onderneming kon vinden, maakte hij toch van diens aanbod gebruik. Anansi kreeg den zak met de twee flesschen spiritus en ging zonder dralen op de tijgervangst.

In het bosch gekomen schreeuwde $\mathrm{Ba}$ Anansi herhaaldelijk, zoo hard als hij kon: "Datra Tigri, O! Kom eens halen! Jou kwajongen, Ba Anansi brengt wat lekkers voor je!' Datra Tigri hoorde Ba Anansi's geroep en lustte dat lekkers graag. Hij wilde zijn schuilplaats echter niet zonder onderzoek aan Anansi verraden, want deze trachtte hem misschien in een valstrik te lokken. Na zich vergewist te hebben, dat het slimme ventje heusch alleen was, sprong hij plotseling te voorschijn en sprak: "hier ben ik, Ba Anansi! Geef mij het lekkers!»

Ba Anansi nam de flesschen spiritus uit den zak en overhandigde ze aan Tigri.

«Kijk eens, Datra Tigri», zeide hij, "welk lekkers ik bedoel. Ik moest hier voorbijgaan, waarom ik aan je dacht en deze twee groote flesschen sterken spiritus voor je kochts. 
$\mathrm{Nu}$ hield Datra Tigiri veel van sterken spiritus en dankte Ba Anansi hartelijk voor diens lekkers. Hij bracht hem naar zijn hol, waar nog nooit iemand anders geweest was. In deze veilige woonplaats dronk Datra beide flesschen spiritus op de gezondheid van den milden gever leeg. Hij hoopte, dat $\mathrm{Ba}$ Anansi meer flesschen spiritus in den grooten zak voor hem brengen zou. Of diende de zak misschien voor wat anders?

Ba Anansi verklaarde, dat hij van alles en nog wat in den zak borg. Voor de aardigheid droegen hij en zijn vrienden elkander soms beurtelings in den zak. Hij wilde Datra Tigri gaarne wijzen, hoe prettig dat toeging. Datra Tigri kon hem eerst dragen, dan zou hij hetzelfde met Datra doen.

Datra Tigri had er niets tegen, dus kroop Ba Anansi in den zak. Daarna rende Tigri met den zak tusschen de tanden naar den zoom van het bosch en vervolgens naar zijn hol terug. Toen kwam Anansi uit den zak en wrong Tigri zich erin, die vroolijk geworden, luidruchtig lachte.

Nauwelijks was Datra Tigri in den zak of Ba Anansi haalde een naald en draad te voorschijn, met welke hij de opening daarvan begon dicht te naaien. Tigri wilde weten, wat Anansi uitvoerde, maar deze maakte hem wijs, dat hij even den gerafelden zak herstelde. Eindelijk was $\mathrm{Ba}$ Anansi klaar met den zak en sleepte Datra Tigri daarin naar 't paleis. Onderweg vroeg Tigri vaak, of Anansi den terugtocht reeds aanvaard had, waarop laatstgenoemde antwoordde dat hij zelfs niet aan den zoom van het bosch gekomen was. Op een bewoonde plaats echter rook Datra gekookt eten en gebood hem brullend naar de wildernis terug te keeren. Met Tigri's woede spottende, verhaastte Anansi zijn schreden en kwam weldra in 't paleis aan.

Ba Anansi legde zijn vracht voor de voeten des konings neer en sprak tot hem: "ik heb Datra Tigri in den zak gevangen, mijn koning, en hem hier voor u gebracht. Laat hem liever zoo in den zak doodslaan, doch niet kappen. Als hij er uit komt, zal niemand hem kunnen houden en zijn wij beiden verloren., Toen vertelde Anansi aan al de omstanders, hoe hij er in geslaagd was Tigri te bemachtigen, en zij luisterden vol bewondering toe. De koning prees zijn list en gaf hem meteen de uitgeloofde premie. Ba Anansi nam dit in ontvangst, dankte Zijne Majesteit en vertrok.

Vreezende voor de diefachtigheid zijner kennissen, ging $\mathrm{Ba}$ 
Anansi stilletjes naar het bosch en legde zich aldaar in een hollen boomstam ter ruste met 't hoofd op zijn schat. Den volgenden morgen vroeg zou hij een gedeelte van het geld bewaren tot later, maar het andere zonder uitstel gaan verbrassen in de stad.

Ondertusschen had de koning ook niet stil gezeten, doch zijn zonen gelast Datra Tigri zonder genade dood te slaan, hetgeen de prinsen zich geen tweemaal lieten zeggen. Allen grepen matta-tiki's (stampers van houten vijzels) en -hamerden daarmee onmeedoogend op den zak. Met volle kracht kwamen de matta-tiki's op het lichaam van Tigri neer, waarom hij van pijn kreunde en dacht, dat zijn stervensuur geslagen had. Maar de driftige koning vergat zich zelf en kapte Datra Tigri met zijn zwaard in diens zitvlak. Onmiddellijk stak Tigri zijn stevige pooten door de snede in den zak, scheurde dezen geheel open en vluchtte weg.

Datra Tigri rende het bosch in, totdat hij moe werd. Om uit te rusten ging hij op den grond zitten, doch moest weer opstaan, want zijn verwond zitvlak deed hem verschrikkelijk veel pijn. Hij nam plaats op een gat in een hollen boomstam, zoodat zijn achterste niet in aanraking met den bodem kwam, dus als op den bril in de beste kamer. Toen lachte hij grimmig bij de gedachte, wat er met $\mathrm{Ba}$ Anansi gebeuren zou, als die bedrieger in zijn handen viel.

Toevallig zat Datra Tigri op den stam, in welken Ba Anansi zonder dit te weten lag. Deze kreeg het benauwd, waarom hij wilde voelen, wat het gat bedekte, en ... betastte met zijn spitse vingertoppen Datra's gewonde plek. Denkende dat muskieten hem staken, sprong Datra Tigri op, sloeg naar de vermeende plagers, en zette zich hierna weder neer. Dit herhaalde zich verscheidene malen, totdat Tigri ten slotte op Anansi's vinger klopte, en diens persoon geheel uit het gat trok. Op 't zien van Ba Anansi brulde Datra Tigri: «hai, boi, hai! (ja, jongen, ja!) ik had niet gedacht, dat ik jou zoo gauw zou pakken! Je hebt mij bijna laten dondslaan, maar ik zal je secuur van kant maken. Je behoeft mij niet om genade te smeeken, want dat is onnoodig. Sterven moet je».

Ba Anansi wendde voor zich in zijn lot te schikken en zeide gelaten: "doe met mij wat je wil, Datra Tigri, wijl je daartoe het recht hebt. Ik verdien straf en zal mij niet ertegen ver- 
zetten, ik verzoek je zelfs mij voorgoed te vernietigen. Men heeft mij reeds zoo dikwijls geslagen, vertrapt, doorstoken, gekapt en opgehangen. Zie eens die litteekens op mijn lichaam. Maar toch leef $\mathrm{ik}$ nog, dus vrees ik zulk een dood ook niet meer. Maak jij een groot vuur en werp mij erin. Dan moet ik verbranden en is de pret uit.»

Datra Tigri dacht, dat Ba Anansi ernstig meende wat hij zeide, en liet hem even los, om den brandstapel gereed te maken. Terwijl Datra daarmee bezig was, klauterde zijn gevangene ongemerkt in een nabijstaanden boom en lachte hem hartelijk uit. Bevend van woede, wilde hij tegen den stijlen stam opklimmen, doch viel achterover op den grond, waarom Ba Anansi nog harder lachte. De geweldenaar ging weer op zijn plaats zitten, waar hij de wacht houden zou, opdat die kwajongen niet aan den vuurdood zou ontkomen. Van vermoeienis echter viel hij in slaap, dus kon Anansi uit den boom klimmen en wegloopen.

Ba Anansi haastte zich naar de stad en vertelde den koning, wat er in het bosch geschied was. Daarop zei de koning, dat hij zich sedert de ontvluchting van Datra Tigri ook niet meer veilig achtte en bood hem weder een groote som gelds aan, om dien gevaarlijken moordenaar aan het gerecht over te leveren. Aanstonds voerde Anansi al de beschikbare politieagenten naar het bosch, waar zij den slapenden Datra verrasten en doodden. Toen marcheerden de agenten vroolijk naar de stad terug en brachten den gedooden moordenaar der vorstin voor hun koning. Ba Anansi bleef een weinig achter, om te zien of al zijn geld nog in den hollen stam was, en kwam kort na de politie in het paleis aan.

Den agenten gaf de koning een groot feest dat vele dagen achtereen duurde. Ba Anansi ontving het beloofde geld, waarmee hij een geruimen tijd feest vierde. Later haalde hij ook het geld in het bosch en trakteerde zich zelf daarmee op de fijnste spijzen en dranken, hetgeen hem lust gaf weer zulk een heldendaad te verrichten.

II. First-move, Get-middle en Done-already. (Eerste beweging, Krijg midden en Reeds klaar).

Eer tien tien, Ba Anansi ontmoette Pa Tigri in het bosch en deelde hem mede, dat hij een kostgrond ging aanleggen. Behalve de noodige gereedschappen, had Tigri ook een goede 
verversching bij zich, namelijk een kolosaal groote $\mathrm{krabasi-}$ godo (holle kalebas schaal) vol honig. Nu hield Ba Anansi veel van zoetigheid en kreeg grooten trek in den geurigen honig. Hij liep met Pa Tigri mede en bood dezen aan hem geheel belangeloos te helpen.

Neen, hij wou geen betaling van $\mathrm{Pa}$ Tigri hebben voor zijn moeite, Pa Tigri was zijn beste vriend en hij zou hem gratis bijstaan. Pa Tigri nam Ba Anansi's aanbod aan en hing vergenoegd de godo met honig aan den afgeknotten tak van een boom in de nabijheid der plek, waar zij samen zouden verbeiden. Hierna leende Tigri eenige gereedschappen aan Anansi en gaf hem verlof de godo van binnen uit te likken, als hij deze leeggedronken zou hebben. Anansi nam de werktuigen van Tigri en prees diens goedheid. Straks zou hij $\mathrm{Pa}$ Tigri zijn dankbaarheid toonen. Hij zou alles met zijn geheele hart voor hem doen.

$\mathrm{Op}$ het uitgekozen terrein hakte Pa Tigri er meteen op los. $\mathrm{Ba}$ Anansi daarentegen trok eerst zijn bovenkleeren langzaam uit en zocht toen naar den diksten boom, om dien voor $\mathrm{Pa}$ Tigri te vellen. Hij hield niet van dingen halfweg doen. Hij wou zwaar voor zijn goeden vriend werken.

Eensklaps schreeuwde Ba Anansi luidkeels: «ja!» alsof hij antwoordde op een geroep in de verte.

"Heeft iemand je geroepen Ba Anansi?» vroeg Pa Tigri, want hij had er niets van gehoord.

"Ja Pa Tigri;» gaf Ba Anansi ten antwoord. "Zie je, mijn tante moest een kind krijgen en wilde dat ik er een naam aan zou komen geven. Ik beloofde haar ook, dat ik het doen zou. $\mathrm{Nu}$ is ze stellig bevallen en laat mij roepen. $\mathrm{Ze}$ is een goede tante voor mij, dus mag ik haar niet te leur stellen. Maar vrees niet, ik ben dadelijk weer hier."

Langs een omweg kwam Ba Anansi bij de godo vol honig en dronk een kwart hiervan op. Hij wou alles verorberen en de zware godo wegdragen, doch hiertoe was hij niet in staat. Daarna keerde hij schielijk tot Pa Tigri terug.

$\mathrm{Pa}$ Tigri was blij zijn helper zoo spoedig weer te zien en wou den naam van het daareven geboren kind weten. Daarop zeide Ba Anansi: "zijn naam is First-move.» Tigri lachte om den aardigen naam en hervatte zijn werk.

Annansị eçhțer bẹweerde, dat hij zijn bijl niet vịndẹn kon, 
Ten einde den honig in zijn maag naar onder te werken, liep hij, naar 't gereedschap zoekende, een beetje rond en gaf tevens zijn voorgewenden wrevel lucht, opdat $\mathrm{Pa}$ Tigri niet achterdochtig worden zou. Waar kon dat vervloekte ding toch zijn? Waarschijnlijk had hij het met de linkerland ergens gelegd en was het daarom niet te vinden.

Plotseling schreeuwde $\mathrm{Ba}$ Anansi even als te voren: «ja!» en deelde $\mathrm{Pa}$ Tigri op diens vraag, wat er te doen was, mede, dat hij bij 't kraambed zijner zuster geroepen werd door haar echtgenoot. Zij waren er beiden opgesteld, dat hij terstond een naam kwam geven aan hun kind. Hierna verwijderde Anansi zich met de belofte niet lang weg te zullen blijven.

Ba Anansi bereikte de godo met honig weder ongemerkt en dronk deze tot op de helft leeg. Toen kon hij niet meer van den inhoud naar binnen krijgen en spoedde zich naar $\mathrm{Pa}$ Tigri terug. Hij liet hem liever niet lang op zijn helper wachten.

Natuurlijk verlangde $\mathrm{Pa}$ Tigri te weten, hoe het jongste kind van Ba Anansi's zuster heette, en Anansi gaf hem de gewenschte inlichting: "het kind heet Get-middle». Tigri vond dezen naam zeer leuk. Hij verzocht Anansi om al de kleine Tigri's, die hij met zijn vrouw krijgen zou, juist zulke geschikte namen te komen geven en ging met zijn werk voort. Ba Anansi had zijn bijl terug gevonden, maar zocht nog steeds naar den diksten boom, hetgeen hij, ter opwekking van zijn eetlust, een geruimen tijd met veel drukte deed. Onderwijl sprak hij hardop tot zichzelf, dat dunne boomen vellen kinderwerk was. Hij was hier niet gekomen, om te spelen, doch om mannenwerk te doen.

Opeens schreeuwde $\mathrm{Ba}$ Anansi weer: *ja!, en bevredigde $\mathrm{Pa}$ Tigri's nieuwsgierigheid toen ook met een leugentje om bestwil. Zijn moeder had een kind gebaard en zijn broertje riep hem. Hij moest het kind nu een naam geven. Doch hij zou straks terugkomen.

Ba Anansi naderde de go do nogmaals ongezien en nu gelukte het hem al den honig daarin op te drinken. Hij likte de godo zelfs geheel schoon. Toen ging hij zijn kleeren, die op Tigri's grond lagen, aantrekken.

$\mathrm{Pa}$ Tigri vroeg $\mathrm{Ba}$ Anansi wederom hoe hij het pasgeboren kind van zijn moeder genoemd had, waarop de honigdief antwoordde: "ik noemde het kind Done-already». Ba Anansi moest hem toen vertellen, hoe hij aan al die mooie namen kwam. 
Daar Tigri juist zijn verversching wilde gaan gebruiken, zeide Ba Anansi: "dat zal je wel spoedig weten, mijn geachte vriend." Zoodra Tigri uit het gezicht was, trok Anansi haastg zijn bovenkleeren aan en verliet de plaats.

Even later ontdekte $\mathrm{Pa}$ Tigri, dat de honig in zijn godo gestolen was, en nu begreep hij aanstonds, waar Ba Anansi die drie aardige namen vandaan had. Brullend van woede, snelde hij naar de opengekapte plek terug, om den schurk te verscheuren, maar deze had reeds het hazenpad gekozen. Tigri doorzocht het geheele bosch, doch kon hem nergens vinden. Anansi was naar de naast bij gelegen bewoonde plaats gevlucht en verborg zich daar in de post' oro (beslagruimte) van een huis. Uit vrees voor $\mathrm{Pa}$ Tigri bleef hij er wonen, om welke reden de spin tot van daag toe altijd nog in de post' oro vertoeft.

\section{Sa Akoeba's koorsoe-enframasi}

(Zus Akoeba's koorts-inflammatie).

Eer tien tien, Ba Anansi was met Sa Akoeba getrouwd, maar wilde haar niet onderhouden. Integendeel verklaarde hij ronduit: «je hebt beloofd mij te zullen gehoorzamen en ik gebied je nu in mijn behoeften te voorzien. Je geeft me alles wat ik noodig heb, of vertrekt op staanden voet. Ik ken genoeg goede vrouwen, die mij beter zullen behandelen, dan jij, als ze mij kunnen krijgen. $Z$ ij lusten mij als een warmen bol.s

Sa Akoeba wilde $\mathrm{Ba}$ Anansi niet ongehoorzaam zijn, doch kon haar veeleischenden man moeilijk alles geven, wat hij verlangde. De arme vrouw overwerkte zich veel te dikwijls en stortte haar hart ten slotte voor Mat Kakalakka (vriendin kakkerlak) uit. "Ik kan het waarlijk niet langer uithouden, Mat Kakalakka», sprak zij. "Zulk zwaar werk zal mij zeker dooden. Als je mij niet hielp, zou ik er al onder bezweken zijn. Ja, je bent een brave meid, doch ik mag niet te veel van je goedheid vergen. $\mathrm{Ach}$, zeg mij toch, wat ik met $\mathrm{Ba}$ Anansi beginnen moet, anders sterf ik van vermoeienis of word stapel gek. s

Mat Kakalakka was een boezemvriendin van Sa Akoeba en woonde bij het echtpaar in. $\mathrm{Zij}$ stond Akoeba in alles bij, maar begreep dat zulk een leventje op den duur ondragelijk zou zijn. Daarom had zij reeds een middel uitgedacht, om er een eind aan te maken, en reide; "ik stook liever geen ruzie tusschen jou en Ba Annansi, doch kạn nịet aanzien, dạt diẹ kerel jou zoo 
afbeult. Wij zullen samen maken, dat hij zijn plicht als echtgenoot vervult, niet met geweld, maar met een listigen streek. Luister. Als Ba Anansi van nacht slaapt, neem je een beetje roucou en kleurt je lichaam daarmede rood. Dan ga je liggen bibberen, zuchten en kreunen. Dat is alles, wat je doen moet. De rest laat je aan mij over en alles zal in orde komen.,

Sa Akoeba vertrouwde Mat Kakalakka volkomen, doch wilde meer van het plan harer vriendin weten. Kakalakka deelde Akoeba daarop haarfijn mede, wat zij zou uitvoeren. Toen ging Kakalakka naar den dokter en stelde hem op de hoogte van de geheele zaak. De goede man had innig medelijden met Sa Akoeba en verzekerde haar vriendin van zijn tnedewerking, waarvoor Kakalakka hem, ook namens Akoeba hartelijk bedankte.

Toen Ba Anansi des nachts rustig sliep, stond Sa Akoeba stilletjes op en wreef haar lichaam met de roucou in. Hierna ging zij liggen bibberen, zoo: «brrr!» terwijl ze onophoudelijk hardop zuchtte: «hm!» en telkens zoo luid mogelijk kermde: "O o i! ik sterf!» Door dit alles gewekt, vroeg Ba Anansi knorrig aan zijn vrouw, wat haar mankeerde, doch zij antwoordde niet. Hij bemerkte spoedig haar roode kleur, die hem hevig verschrikte. Hij riep Mat Kakalakka wakker en smeekte haar om goeden raad. Kakalakka vond, dat Sa Akoeba ernstig ziek was, en zond hem met geveinsde ontsteltenis direkt naar den dokter. Ja, die arme vrouw had waarschijnlijk koorsoe-enframasi. Hij moest niet dralen, want die roode kleur van zijn vrouw beteekende niets goeds, misschien zelfs haar dood. En Anansi ging gauw zijn huisdokter roepen, bij wien Kakalakka des morgens reeds geweest was.

Een half uurtje later kwam Ba Anansi met den dokter terug. Deze onderzocht Sa Akoeba en schudde bedenkelijk het hoofd. Door zwaar werk en slechte voeding had zij een vreeselijke besmettelijke koorts gekregen, van welke de roode gloed haar lichaam verteerde. $Z$ ij mocht zichzelf nooit meer vermoeien, anders stond hij niet voor haar leven in. Ba Anansi moest de zieke goed voeden en tevens wijn laten drinken. Als dat niet geschiedde, zou zij sterven en had hij schuld aan haar dood.

$\mathrm{Ba}$ Anansi vreesde zijn geweten met Sa Akoeba's dood te bezoedelen, doch kon de noodige spijzen en dranken niet bekostigen. Hij vroeg den dokter dus wat geld ter leen en zwoer hem het dubbele daarvan terug te zullen geven. De dokter 
keek Anansi evenwel geringschattend aan, alsof deze een kraal zonder gat was, toonde hem zijn ledige zakken en verliet de woning. Daarna wendde Ba Anansi zich tot Mat Kakalakka en bad haar om hem uit zijn verlegenheid te redden. Doch Kakalakka had zelf geld noodig, dus kon zij hem ook niet helpen. Teneinde raad, drukte Anansi zijn hoed diep over het voorhoofd en ging de deur uit, zeggende, dat hij voor het aanbreken van den dag weer thuis zou zijn.

$\mathrm{Na}$ veel moeite gelukte het $\mathrm{Ba}$ Anansi eindelijk een winkel binnen te dringen, waar hij al 't geld, dat er in de lade was, ontvreemdde. Thuisgekomen, legde Anansi het geheele bedrag voor Kakalakka op tafel. Ze kon daarmee koopen, wat Sa Akoeba noodig had. Neen de arme vrouw mocht niet door zijn toedoen sterven.

Mat Kakalakka kocht van alles meer dan genoeg en kookte driemaal 's daags heerlijk eten. Sa Akoeba at de allerbesten kost en drank, zooveel wijn als zij maar lustte. Mat Kakalakka vulde haar eigen buikje met een deel van de heerlijke spijzen en dranken, anders zou zij ongeschikt zijn voor ziekenverpleegster. Ba Anansi kreeg slechts de overschotjes der maaltijden, doch stelde zich daarmee volkomen tevreden. Hij zou het zichzelf nooit kunnen vergeven, als Sa Akoeba van gebrek omkwam, en haar geest zou hem geen oogenblik met rust laten,

Naarmate Ba Anansi's geld opraakte, werd Sa Akoeba beter. $Z_{i j}$ kon reeds opstaan en eenig huiswerk verrichten. Ba Anansi was daarmee niet tevreden en overlaadde haar opnieuw met werk. Doch toen kreeg Akoeba weer die gevaarlijke binnenkoorts met den verteerenden rooden gloed, waarvoor hij zoo bang was. Hij stal ditmaal genoeg geld van een rijken bankier en gebruikte het voor Akoeba's gezondheid.

Zoo verviel Sa Akoeta in dien verschrikkelijken koortsachtigen toestand, iederen keer als Ba Anansi haar wilde afbeulen en stal hij telkens het geld voor de versterkende spijzen en dranken. Daardoor werd het politietoezicht zoo verscherpt, dat Anansi niet meer stelen kon en naar een eerlijk baantje zocht. Daar het onderhoud van zijn gezonde vrouw hem nu minder kostte, dan haar genezing van die.levensgevaarlijke koorts, bleef hij aan 't werk en deed trouw zijn plicht als echtgenoot. 


\section{Omoe Tigri's Tara-Poptji. (Oom Tijgers Kleefpop).}

Eer tien tien, Omoe Tigri bezat een groot rijstveld, waarin het rijpende produkt des nachts gestolen werd. Op raad van zijn buren, Ba Anansi en diens vrouw Sa Akoeba, hield hij er de wacht, of plaatste er vallen en stilletjes, maar kon de dieven niet pakken. Anansi en Akoeba hadden Tigri beloofd, dat rij met hun familie zijn rijst voor hem oogsten zouden, doch stelden het iederen dag uit. Omoe zag, dat er ten slotte geen korrel rijst zou overblijven en maakte daarom zelf een tara-poptji, waardoor de dieven gepakt of tenminste afgeschrikt moesten worden. Hij plantte namelijk een met tara (kleefstof) besmeerden paal midden in het rijstveld en hing er een met stokken opengehouden jas aan, zoodat het toestel in de duisternis precies op een man geleek. Vol bewondering keek hij naar zijn werk en wachtte geduldig af, wat er verder gebeuren zou. Hij zou gaarne Ba Anansi's opinie over de tara-poptji vernomen hebben, doch zijn vriend bezocht hem dien dag toevallig niet. Als dat ventje en zijn Akoeba morgen bij hem kwamen, dan waren de dieven misschien reeds gevangen.

Het was gelukkig voor Omoe Tigri, dat Ba Anansi en Sa Akoeta niets van zijn tara-poptji wisten want deze waren zelf de dieven. Met hun beiden gingen ze dien nacht ook wat rijst stelen en zagen er de tara-poptji staan. Zij waren zeker, dat Tigri er niet zonder hun voorkennis komen zou en hielden het toestel daarom voor een vreemden dief. Die mocht daar geen rijst komen stelen. Hij moest uit het rijstveld verdreven worden, of zou hun ongetwijfeld nadeel berokkenen.

Sa Akoeba stiet den dief tegen zijn borst en joeg hem als een hond weg. Maar de kleverige dief hield haar handen stevig vast zonder zich van daar te verwijderen. Zij beval den schelm driftig haar handen onmiddellijk los te laten en trachtte hem terzelfdertijd van zich of te schoppen, doch hij pakte haar voeten eveneens beet. Alzoo kon zij zich niet meer verroeren en riep anstig haar echtgenoot te hulp, die zijn zak reeds half met rijst gevuld had. $\mathrm{Ba}$ Anansi snelde meteen toe, om haar te bevrijden, maar de dief plakte hem ook aan zich vast. Geen raad meer wetende, barstten beiden in tranen los en smeekten hun vreemden collega om genade. Als hij hen vrijliet, zouden zij al Tigri's rijst voor hem stelen. $\mathrm{Zij}$ zouden hem levenslang dienen. Ja, ten allen tijde kon hij op hen 
rekenen. Ze zouden hem nooit teleurstellen. Ach, hij moest hen niet langer gevangen houden! Maar de nacht verliep, zonder dat ze hun vrijheid terug kregen.

Bij het aanbreken van den dag kwam Omoe Tigri eens kijken, of de dieven al door zijn tara-poptji gevangen waren, en vond er $\mathrm{Ba}$ Anansi en Sa Akoeba werkelijk aan vastgeplakt. Op 't zien zijner twee kennissen brulde hij grimmig en vroeg hun, wat of dat beteekende. Beiden beweerden daarop, dat zij den dief voor hem hadden willen pakken, maar de half met rijst gevulden zak getuigde tegen hen. Zonder zich aan hun gevoelsuitdrukkingen te storen, nam hij zijn lederen buikriem en sloeg hen daarmee zoo verschrikkelijk, dat ze van de kleefpop afvielen. Ba Anansi kende Omoe Tigri en was blij er met een pak ransel afgekomen te zijn. Doch Sa Akoeba vreesde voor geen man ter wereld, dus kon zij zich zoo iets niet laten welgevallen. $\mathrm{Zij}$ schold Tigri uit voor al wat slecht was en hij liet haar begaan, tot zij met haar brutalen mond tegen zijn overleden moeder durfde uitvaren. Toen werd hij toornig en verscheurde haar zonder genade.

Sedert dien tijd had Omoe Tigri geen last meer van dieven in zijn veld en oogstte er de rijst heel vergenoegd met betaalde hulp. Ba Anansi trouwde een andere Akoeba, met wie hij even ongelukkig leefde als met de vorige.

\section{Waarom Ba Anansizoobang voor Ba Dede (Broer Dood) is.}

Eer tien tien, Ba Anansi ging diep in het bosch jagen en zag er Ba Dede voor een kamp zitten. De bekwame vanger droogde het vleesch der vele dieren, die hij met zijn vallen gevangen had, op een basbakotto (indiaanschen rooster). Hij nam geen notitie van $\mathrm{Ba}$ Anansi, die naderbij komende, sprak: "hoe gaat het toch, Ba Dede? Wat een massa vleesch heb je hier! Je bent gelukkiger geweest, dan ik. Ja, ik heb niets geschoten. Platzak moet ik thuis gaan, waar mijn hongerige familie op mij wacht. Sa Akoeba gaat boos op mij worden, als ik geen toespijs voor haar en de twaalf kinderen breng. Ik blijf liever met je slapen, dan haar met leege handen onder de oogen te komen. Je moest mij wat vleesch van je geven, man, al is 't niet veel.

Da Dede gaf Ba Anansi geen antwoord, waarom deze herhaalde malen vroeg, of hij niet een paar stukken gedroogd 
vleesch mocht hebben. Toch bleef Dede zwijgen, hetgeen Anansi als diens toestemming beschouwde. Hij nam genoeg vleesch van de basbakotto en stopte het in zijn jachtzak. Na Ba Dede grantangi (grooten dank) gezegd te hebben, verliet hij het kamp en keerde naar huis terug.

Toen Ba Anansi thuis gekomen was, sprak hij tot zijn vrouw: «kijk eens in mijn jachtzak en je zult er wat mooi gedroogd vleesch in zien. Maak het lekker klaar voor ons beiden en de kinderen. Je behoeft er niet zuinig mee te zijn, want morgen krijg je veel meer van mij. Maar gauw, hoor!» En Akoeba bereidde een heerlijk vleeschmaal, dat ze met hun veertienen smakelijk opaten.

Den volgenden morgen begaf $\mathrm{Ba}$ Anansi zich met een kruiwagen naar het kamp, waar Ba Dede evenveel vleesch op de basbakotto droogde, als daags te voren. Anansi vroeg hem weer herhaaldelijk eenige stukken van dit vleesch, doch ontving ook nu geen antwoord. Haastig laadde hij bijna al het vleesch op zijn kruiwagen, dankte Ba Dede en keerde met zijn vracht huiswaarts. Sa Akoeba gebruikte slechts een gedeelte van het vleesch voor het avondmaal en bewaarde de rest, waaraan de geheele familie wel drie dagen lang genoeg had.

Zoo haalde $\mathrm{Ba}$ Anansi geregeld een kruiwagen vol vleesch bij $\mathrm{Ba}$ Dede, maar gaf er hem niets voor. Anansi gevoelde dat hij misbruik maakte van Dede's goedheid, en dit maakte hem z.eer ongerust. Ba Dede liet hem nu stilletjes begaan, doch zou 't zich niet altijd laten welgevallen. Als zijn stille vriend maar niet kwaad werd en hem met dien dikken knots doodsloeg. Neen, dat zou nooit gebeuren. Ba Dede leefde daar zoo eenzaam en had zeker een vrouw noodig. Hij kon Dede zijn oudste dochter brengen, dan zou deze verplicht zijn hem levenslang vleesch te geven. Doch Sa Akoeba mocht de waarheid niet weten, want zij zou haar dochter nimmer aan Dede afstaan.

Ba Anansi vertelde Sa Akoeba, dat hij een goede werkplaats voor hun volwassen dochter gevonden had en dat deze het daar heerlijk zou hebben, omdat ze er slechts voor een heer zorgen moest. Akoeba had graag dat haar dochter bij een ongehuwden heer werkte, maar wilde toch weten, wie hij was. Anansi beloofde haar in kennis met hem te zullen brengen en kreeg terstond vergunning om de'jonge maagd naar haar eerste werkplaats te geleiden. 
In 't kamp gekomen, trad $\mathrm{Ba}$ Anansi naar voren en stelde zijn dochter aan Ba Dede voor, die geen woord sprak. Hij stond zwijgend toe, dat Anansi nog een kruiwagen met vleesch nam, doch keek zijn aanstaande vrouw niet eens aan. Het gulzige meisje bekommerde zich daar weinig om, want Ba Anansi had haar verzekerd, dat zij er geregeld volop vleesch te eten zou krijgen. Gedurende haar vaders afwezigheid liep ze evenwel in een van Dede's vallen en verloor het leven.

Den eerstvolgenden keer dat Ba Anansi om vleesch in het kamp kwam, bemerkte hij het lijk van zijn dochter op de basbakotto. Toornig sneed hij een dikke krabasi-wipie (kalebas zweep) en begon Ba Dede daarmee geducht af te ranselen. Toen vergrootte deze zichzelf en greep zijn zwaren knots, om hem te verpletteren. Op het zien daarvan, zette Ba Anansi het op een loopen, maar Dede ijlde hem verwoed achterna.

$\mathrm{Ba}$ Anansi snelde zijn woning binnen, maar Ba Dede volgde hem zoo dicht op de hielen, dat hij onmogelijk de deur achter zich kon sluiten. Vlug klom hij tegen den wand op, gevolgd door Sa Akoeba en de kinderen, die het gevaar hadden zien aankomen. Allen bereikten den nokbalk van het huis, welken zij vastgrepen om er doodelijk verschrikt aan te blijven hangen, totdat Ba Dede zich verwijderde. Beneden stond Dede met zijn knots in de vuist op hen te wachten en keek bijwijlen grijnzende naar boven.

$\mathrm{Na}$ een poosje snikte het jongste en zwakste kind: «tje (ach), papa help mij! mijn handen zijn zoo moe, dat zij den balk niet meer kunnen vasthouden. Mijn vingers glijden er reeds af. Dadelijk ga ik naar beneden vallen, dan zal Ba Dede mij vermoorden. Maar Ba Anansi snauwde het toe: "Ba Dede kan je gerust vermoorden, want je at maar raak van het vleesch, dat ik thuis bracht, zonder zelfs te weten hoe ik eraan gekomen was. viel het stumpertje op den grond en werd door Ba Dede morsdood geslagen.

Zoo geraakten al de kinderen vermoeid, de zwakkere voor de sterkere en klaagde ieder snikkend zijn nood, op welk gejammer Ba Anansi telkens zijn bitse woorden herhaalde. Alnaar de kracht hen begaf, stortten de uitgeputte kleintjes neder en sloeg Ba Dede woedend het eene na het andere dood.

Daarna wende Sa Akoeba zich, evenals haar kinderen, snikkend tot $\mathrm{Ba}$ Anansi, maar deze gaf haar ook ten antwoord, dat zij maar raak van het vleesch had gegeten, dat hij thuis bracht, 
zonder zelfs te weten hoe hij er aan gekomen was. $Z$ ij viel vlak voor de voeten van $\mathrm{Ba}$ Dede neer, die haar met een geweldigen slag van zijn knots afmakte.

Toen hing Ba Anansi alleen aan den balk, doch hij werd eveneens moe. Hij keek naar omlaag en zeide tot den bleeken Dede: "Mijn handen zijn reeds vermoeid, dus ga ik dadelijk vallen, gelijk mijn vrouw en kinderen. Maar ik verdien de zwaarste straf en wil die ook lijden. Neem wat asch uit het vat daar en zet het op den grond onder mij. Als ik erop neerkom, sterf ik secuur op een vreeselijke wijze en zal je voldaan zijn over je werk.

Ba Dede bestrooide de aangewezen plek met de asch, waarin Ba Anansi zoo tuimelde, dat er een massa van opstoof en Dede's oogen vulden. Geheel verblind wreef Dede zich de asch uit de brandende oogen, van welke gelegenheid Anansi gebruik maakte om naar de post'oro te vluchten. Kort daarna opende Dede weer zijn oogen, maar kon Anansi niet doodslaan, wijl deze spoorloos verdwenen was. Deze zocht er hem een geruimen tijd lang vergeefs en ging toen zeer ontevreden naar zijn kamp in het bosch terug.

Om deze reden is $\mathrm{Ba}$ Anansi tot vandaag nog zoo bang voor Ba Dede, dat hij in de post'oro woont en bij het minste onraad daar heen snelt, ten einde zich te verbergen.

VI. Hoe Ba Anansi aan zijn dun middellijf kwam.

Eer tien tien, Ba Anansi was de man van Sa Akoeba, bij wie hij vele kinderen had. Akoeba hield er een groote fokkerij van koeien, varkens, kalkoenen, eenden, kippen en duiven op na, maar slachtte deze uitsluitend bij feestelijke gelegenheden of voor zichzelf en de kinderen. Ba Anansi mocht in beide gevallen slechts de beentjes hebben, hetgeen hem natuurlijk niet beviel, waarom hij er vaak over klaagde. Sa Akoeba schold hem dan uit voor al wat lui was. $Z$ ij zeide, dat hij volstrekt geen recht op haar eigendom had, liever zijn mond moest houden en gaan werken. Aan dit leventje wilde Anansi spoedig een einde maken, en wijl hij het niet op een eerlijke manier kon doen, zou hij het daarom met een streek beproeven.

Op een avond wendde Ba Anansi voor in den slaap door een boozen geest bezield te zijn, die met een diep neusgeluid door zijn mond sprak, zoodat Sa Akoeba het duidelijk hoorde: 
"ik ben de apoekoe (zwarte geest) van het schuimende termietennest in den hollen boomstomp, nabij den hoogen $\mathrm{kan}$ kantri (vereerden boom). Iedereen op deze plaats behoort mij te dienen. Sa Akoeba moet dagelijks lekkere spijzen met het vleesch harer kweekjes bereiden en die in den hollen boomstomp voor mij zetten. Wanneer dit offer niet aan mij gebracht wordt, zal de heele familie hier krankzinnig sterven». De bijgeloovige Akoeba luisterde verschrikt naar die onheilspellende woorden en kon den geheelen nacht niet slapen.

Den volgenden morgen stond $\mathrm{Ba}$ Anansi vroeg op, om uit te gaan. Sa Akoeba vertelde hem, wat er in den afgeloopen nacht voorgevallen was, doch hij scheen er niets van te weten. Hij zeide, dat 't hem weinig kon schelen, wat zij met haar eigendom deed, en haastte zich naar het bosch. Met zijn houwer holde hij er den boomstomp naast den vereerden kankantri uit als een kom. In den bodem van de holte boorde hij een gat loodrecht naar beneden en door den geheelen stomp heen. Onder deze opening nam hij plaats, haalde een flesch vol zeepwater uit zijn zak en wachtte daarmee op Sa Akoeba.

Kort nadat $\mathrm{Ba}$ Anansi zich in den boomstomp verborgen had, kwam Sa Akoeba eens kijken, of er zich waarlijk een a poekoe bevond. Ba Anansi vulde zijn mond met zeepsop en blies dit door het gat heen, zoodat het schuimend in de komvormige holte opborrelde. Dat schuim ziende, week Sa Akoeba ontsteld achteruit, waarna zij hardop tot zichzelf sprak: "ja, er is een a poekoe in dezen boomstomp en een kwaadaardige ook. Ik zal dezen geest geregeld lekkere vleeschspijzen brengen, opdat hij ons allen niet krankzinnig doet sterven. Neen, ik kan niet langer naar het schuim van den a poekoe kijken, want het maakt mij reeds akelig. Ik zal nu naar huis gaan, om God voor zijn goedheid te danken, want $\mathrm{Hij}$ deed mij zelf hooren, wat de geest bij monde van $\mathrm{Ba}$ Anansi zeide. Ik zou het anders niet gelooven en dan zouden ik en de mijnen verloren zijn.» Toen keerde zij naar huis terug, waar $\mathrm{Ba}$ Anansi wat later verscheen en in kennis gesteld werd met de aanwezigheid van den gevaarlijken a poekoe daarginder, om welken kantamasoe (termieten geest) hij zich niet bekommerde.

Het viel Sa Akoeba zwaar haar kweekjes voor den a poek oe te slachten, maar er was niets aan te doen. $\mathrm{Zij}$ moest hem, ter wille van zich zelf en de haren, met vleeschspijzen voeden en 
deed het ook. Elken dag maakte zij een groote kom vol eten klaar en ledigde die in de holte van den boomstomp met de woorden: "zie je, mijn tata (vader), ik schenk je volgaarne dit voedsel, dus moet je mij geen kwaad doen en mijn familie met rust laten.» Het eten gleed door de kleine opening naar beneden, waar $\mathrm{Ba}$ Anansi telkens reeds verscholen zat en het met zijn mond of zijn handen opving. Op deze wijze at hij zooveel dat zijn buik er bijna van barstte. Aldus verminderden de kweekjes van Akoeba gestadig in aantal, terwijl zij en de kinderen vermagerden. Deze waren niet tevreden met hetgeen ze van hun moeder te eten kregen, namelijk bananen of rijst zonder toespijs. $\mathrm{Zij}$ murmureerden daarover eerst bij zichzelf en zeiden het tenslotte ronduit. Sedert dat hun vader van dien a poekoe gedroomd had, moesten zij hongerlijden, terwille van hun gezondheid. Misschien speelde papa zelf voor geest. Hij was nooit thuis als mama naar het bosch ging. Zij gaf hem bijna geen eten en toch werd hij in den laatsten tijd dik.

De woorden der kinderen stemden Sa Akoeba tot nadenken, waarom zij vermoedde, dat Ba Anansi haar bedroog. Maar zij durfde hem nog niet in den boomstomp zoeken en zon op een veiliger manier om achter de waarheid te komen. $\mathrm{Zij}$ kookte een grooten pot soep en goot den inhoud daarvan met behulp der kinderen onafgekoeld in den uitgeholden boomstomp, zeggende: * hier heb je voor 't laatst wat warme soep, mijn baas. Ik zal je geen eten meer kunnen brengen, want mijn voorraad is op.» $\mathrm{Ba}$ Anansi had zijn mond reeds aan de opening gebracht, dus kwam de brandend heete soep daarin terecht. Hij nam zijn mond met een pijnlijken kreet weer van de opening af waardoor de rest der soep op zijn hoofd viel en hem ook in 't gelaat hevig brandde. Dat was te veel voor Anansi, die luidkeels schreeuwde: "wai, Sa Akoeba! Je brandt me ooi! Help ooi!»

Op 't hooren der stem vreesde Sa Akoeba niet meer en haalde $\mathrm{Ba}$ Anansi uit zijn schuilplaats te voorschijn. $Z$ ij rammelde hem voor de oogen der kinderen dooreen, totdat zijn middellijf er dun van werd en hij naar de post'oro snelde, om er uit schaamte voor zijn misvormd lichaam, te blijven wonen.

Zoo kwam Ba Anansi aan zijn dun middellijf. 
VII. Hoe Ba Sekrepatoe (Broer Schildpad) zooveel kappen in zijn rugkreeg.

Eer tien tien, Mat Tiengifowroe (Vriend Stinkvogel) zou zijn geboortedag achter de wolken vieren en noodigde al de vogels op 't luchtfeest uit. Anansi spon een lang stuk van zijn touw, welks uiteinde hij op den bepaalden dag door een betrouwbaren vogelvriend aan de wolkenmassa liet vastmaken. $\mathrm{Hij}$ klom langs het touw naar boven en verscheen op 't feest. Sekrepatoe nam veeren van de vogels, met welke hij gemakkelijk twee groote vleugels vormde en bijtijds naar 't feest vloog.

Toen 't feest ten einde liep, kreeg Ba Sekrepatoe ruzie met de vogels, waarom deze woedend hun veeren uit zijn valsche vleugels trokken, van welke er tenslotte geen meer overbleef. Hierna vlogen zij alle weg en lieten hem op een donkere wolk achter. Angstig keek hij rond en riep Ba Anansi te hulp, die gelukkig nog niet heengegaan was: «Ba Anansi oh! Die vogels hebben hun veeren terug genomen, dus bezit ik geen vleugels meer om te vliegen! Kun je me niet naar omlaag helpen. Ik zal je daarvoor levenslang dankbaar zijn en je te eeniger tijd weder een dienst bewijzen. Anansi wilde Ba Sekrepatoe gaarne helpen, maar deze moest hem belooven, dat hij voor zichzelf zou houden, wat zijn oogen ook zagen. Hij verklaarde, dat vele personen niet konden zien en zwijgen, wat hem geenszins beviel. $\mathrm{Hij}$ zou Ba Sekrepatoe straks naar beneden laten, doch wenschte niet begluurd te worden, terwijl dit geschiedde. Als Ba Sekrepatoe toch opkeek, zou het hem zeker berouwen.

Ba Sekrepatoe zwoer, dat hij zou gehoorzamen en zwijgen, waarna $\mathrm{Ba}$ Anansi op den rand van de wolk ging zitten en hem met zijn touw voorzichtig liet zakken. Een eindje lager gekomen keek de nieuwsgierige Sekrepatoe steelsgewijze naar omhoog en riep verbaasd uit: "na $\mathrm{Ba}$ Anansi gogodi paroeteteiso (brengt Broer Spins achterste zóó touw voort)?!»

Daarop vroeg Ba Anansi: "wat zeg je daar, Ba Sekrepatoe?» En Sekrepatoe antwoordde haastig: "niets Ba Anansi. Ik wenschte slechts, dat ik reeds veilig beneden was».

Hetzelfde vond op verschillende afstanden tusschen hemel en aarde plaats, totdat Ba Anansi duidelijk verstond, wat Ba Sekrepatoe uitgeroepen had. Toen werd hij woedend kwaad op Sekrepatoe, sneed zijn touw door en liet hem op den grond vallen. Sekrepatoe 
kwam er met een geweldigen slag op zijn gladden rug terecht, waardoor hij zich vreeselijk kwetste en een tijd lang bewegenloos bleef liggen.

Zoo kreeg Ba Sekrepatoe al deze kappen in zijn rug, die er tot nu toe te zien zijn.

\section{Wan gogo njamsi, wan beti.} (Een stoel jams, een beet).

Eertien tien, Er heerschte een groote hongersnood en alleen Ba Makka-sneki (Broer Makkaslang) had ja ms in zijn kostgrond. $\mathrm{Nu}$ hield hij veel van bijten, maar kon geen slachtoffers meer vinden. Hij wou iedereen gaarne een stoel ja m geven, om hem slechts één beet te mogen toebrengen, doch niemand nam zijn jams aan. Hij liep overal rond uitroepende: kwan gogo njamsi, wan beti!» maar te vergeefs. Men wist, dat zijn beet doodelijk was, en ging hem uit den weg.

Doch Ba Anansi lustte de ja m s van Makka-sneki heel graag en zeide tot zijn vrouw: "Abeni, ik ga dien stoel jams nemen».

Daarop verklaarde Abeni ronduit: «ik wil niets met deze zaak te maken hebben, omdat je sterven zult, indien Ba Makka-sneki je bijt». Ba Anansi stoorde zich niet aan haar woorden en verzocht Makka-sneki vriendelijk de jams voor hem te brengen. Ba Makkasneki mocht hem gerust bijten zoodra hij van de ja ms gegeten had.

Des morgens stond $\mathrm{Ba}$ Anansi zeer vroeg op en zette den geheelen stoel jams in een grooten pot water op vuur. Nauwelijks was hij daarmee klaar, of Ba Makka-sneki trad sbinnen en wilde hem bijten. Anansi ontstelde hevig en zeide: "kijk eens, Ba Makkasneki, al je jams is daar nog ongekookt in den pot. Je moogt mij voorloopig niet bijten, omdat ik er zelfs geen stukje van geproefd heb. Blijf zoolang bij 't vuur zitten, anders vat je misschien kou. Je houdt van de warmte en kan er een beetje knikkebollen. Ik ga weer liggen slapen, tot de zon opkomt. Tegen dien tijd is de jams al zacht gekookt, die ik smakelijk zal komen opeten. Je kunt mij dan bijten, waar je wilt». Toen klom hij naar zijn zoldertje, terwijl Makka-sneki dicht bij 't vuur plaats nam.

Gelijk Ba Anansi verwacht had, begon Ba Makka-sneki dadelijk door de warmte van 't vuur te knikkebollen en viel spoedig in slaap. Dat ziende, nam Anansi een langen scherpen priem, dien hij bij wijze van een vork in den pot stak, uit welken hij zijn buik vol jams at, zonder den zolder te verlaten. $Z_{\text {ijn }}$ vrouw 
en kinderen aten op dezelfde wijze met hem mee, waarom er geen $\mathrm{jams}$ meer in den pot over bleef.

Toen de zon opkwam, ontwaakte Ba Makka-sneki, die zich geeuwend uitrekte. Terstond ging $\mathrm{Ba}$ Anansi naar beneden, keek in den pot en sprak schijnbaar ontstemd: "waarom behandel je mij zoo dan, Ba Makka-sneki? Je hebt al de jams in den pot gegeten en er niets voor mij gelaten. Strijdt niet tegen, man, want er was niemand anders hier, dan jij! Maar Makka-sneki ontkende het feit bedreven te hebben met een wantrouwenden blik op zijn beschuldiger. Anansi was daarmee niet tevreden. Hij verlangde dat ze een eed voor elkander zouden afleggen, hetgeen Makka-sneki goed vond.

$\mathrm{Ba}$ Anansi haalde vlug een lang slagersmes uit de keuken, liet zich den verkeerden kant daarvan door den dommen $\mathrm{Ba}$ Makka-sneki op de keel zetten en sprak: "ik zweer bij mijn leven, dat ik de jams in den pot niet genomen heb! Dit mes mag mijn hals afsnijden, als ik lieg. Makka-sneki trok den meineedige ook den botten rug van het lemmet met een forschen ruk over de keel, zonder hem natuurlijk in het minst te kwetsen, hetgeen evenwel als een overtuigend bewijs van zijn onschuld gold.

Ba Makka-sneki moest denzelfden eed doen onder het mes. Hij zwoer bij zijn leven, dat hij de jams in den pot niet genomen had en zeide, dat 't mes zijn hals mocht afsnijden, als hij loog. Ba Anansi haalde echter den scherpen snijrand van het lemmet over Makka-sneki's keel en sneed zoo diens hals geheel van den romp af. Hierna legde Anansi beslag op Makka-sneki's kostgrond in welken hij genoeg $\mathrm{jams}$ vond, om hem en de zijnen uit den hongersnood te helpen.

\section{Wat de holte in Ba Anansi's borst veroorzaakte.}

Eer tien tien, Ba Anansi bezat twaalf wrokobakroe's (zwarte werkgeesten), die hem bij al zijn werk hielpen. Op deze wijze verdiende hij zonder moeite veel geld, zoodat zelfs zijn vrouw Sa Akoeba en zijn tien kinderen geen gebrek leden, maar een lekker leventje hadden. Men moest ' $t$ zien, om het te gelooven.

Op een middag had Ba Anansi weer met behulp van zijn wrokobakroe's een vaam hout gekapt en kwam hongerig thuis. Hij wilde zijn eten meteen hebben, doch Sa Akoeba had het nog niet gekookt en verzocht hem een beetje te wachten. 
Dat ontstemde Anansi ten zeerste, die naar aanleiding daarvan zijn ontevredenheid over al haar tekortkomingen uitsprak. Akoeba liet zich niet ongestraft bekapittelen en vertelde hem op haar beurt eens flink de waarheid. Daardoor ontstond een hevige woordenwisseling, waarbij zij elkander de vuilste woorden toevoegden.

Ba Anansi en Sa Akoeba maakten zich zoo driftig, dat zij handgemeen werden. De kinderen trachtten hun moeder te helpen, maar Anansi dreef hen met klinkende oorvijgen terug. Nu dachten de wrokobakroe's, dat het toedienen der slagen tot de werkzaamheden van hun meester behoorde, en snelden hem te hulp. Zij rammelden eerst Sa Akoeba dood en hierna de kinderen. Woedend op de al te gedienstige wrokobakroe's, wierp Ba Anansi het huisraad door elkaar, waarna hij met de vuisten tegen de wanden sloeg. Dit alles rekenden de wrokobakroe's als werk, dat $z$ ij op hun manier voor Anansi voltooiden. ' $Z$ ij vernielden het huisraad en haalden zijn woning neer, uit welke hij hals over kop snelde.

Buiten staande klopte Ba Anansi zich driftig op de borst, terwijl hij dreigend uitriep: 'ik Anansi haanh! ${ }^{1}$ ); ik Anansi haanh!» De wrokobakroe's hielden dit kloppen voor werk en kwamen hun aandeel ervan doen. Zij klopten Ba Anansi op de borst, tot hij er een diepe wonde kreeg. Toen liet Ba Anansi zich languit op den grond vallen en wendde volslagen levenloosheid voor. Op 't zien daarvan keerden de wrokobakroe's tot hun oorsprong terug, dus was Anansi voor goed van hen bevrijd.

Wanhopig door het geleden verlies, verliet $\mathrm{Ba}$ Anansi de plaats des onheils en ging in de post'oro wonen. Hij genas er zijn wonde, maar deze veroorzaakte de holte in zijn borst, die er nog steeds in voorkomt.

$X$. Het ontstaan van Mat Lantaarndragers ${ }^{2}$ ) (Vriend Lantaarnvliegs) eigenaardigste gewoonte.

Eer tien tien, Ba Anansi ging bij maneschijn alleen uit, maar werd op donkere avonden door Mat Lantaarndrager voorgelicht of bleef thuis. Mat Lantaarndrager kon bij te veel licht

1) Uitroep van bedreiging,

") Met „lantaarndrager" wordt een soort lichtende kniptor bedoeld. 
niet goed zien en liet rich op maneschijnavonden altijd door Ba Anansi geleiden. Zoo kwam 't, dat die twee steeds de beste vrienden ter wereld waren, in weerwil van hun verschillende levenswijzen.

$\mathrm{Op}$ een avond ging $\mathrm{Ba}$ Anansi op bezoek bij Mat Lantaarndrager, die juist van de vischvangst thuisgekomen was en een korfje vol visch voor 't avondmaal klaar makkte. Hij verzocht Anansi bij hem te blijven eten, welke uitnoodiging zijn $\mathrm{Ba}$ (Broer) aannam. Zij zetten zich dus aan tafel, waar Ba Anansi op een verwijtenden toon sprak: "je behandelt mij niet goed, Mat Lantaarndrager. Wij zijn oude vrienden en toch ga je geregeld visschen zonder mij mede te nemen. Je weet, dat ik reeds lang gebrek aan toespijs heb, doch wil mij niet eens een paar visschen laten vangen. Neen, dat is niet mooi van je.*

Mat Lantaarndrager zei daarop: "je moet mij niet kwalijk nemen, $\mathrm{Ba}$ Anansi, maar ik breng liever niemand naar 't vischgat. ${ }^{1}$ ) De oude negers zeggen: "mi boenhati na mi kotineki (mijn goedhartigheid is mijn "hals afsnijden»)». Als je een maal weet, waar het vischgat is, dan ga je niet meer doen, wat ik je zeg, doch wat jij wilt en dan loopt het zeker mis. Ja, ik moet voorzichtig zijn, want iemands beste vriend is soms zijn grootste vijand.» Maar hij gaf ten slotte aan Anansi's bede gehoor en stemde er in toe hem over twee avonden uit visschen te brengen. Anansi behoefde geen grooten korf met zich mee te nemen, omdat zij toch niet lang in 't vischgat zouden blijven.

Op den bepaalden avond ging $\mathrm{Ba}$ Anansi met een groote krampa (sleepmand) en een kolossalen vischkorf beladen, Mat Lantaarndrager halverwege te gemoet, die hem op weg naar 't vischgat zou komen af halen. Lantaarndrager wilde weten waarom Anansi toch zoo'n grooten korf meebracht, waarop Ba loog, dat hij geen kleineren bezat. Voorgelicht door zijn Matti (Vriend), volgde Anansi langzaam 't snalle pad, dat door het struikgewas naar het verafgelegen vischgat voerde.

Mat Lantaarndrager en $\mathrm{Ba}$ Anansi bereiken eindelijk de plaats hunner bestemming, waar beiden terstond in 't vischgat nederdaalden. Zij voelden er in de holen naar visschen, terwijl Anansi tevens zijn krampa gebruikte. Spoedig vulde Lantaarndrager

1) Vischgaten zijn de diepere plekken in de moerassen, welke in het droge seizoen niet droogloopen en waarin de boschvisschen zich verzamelen. 
zijn korfje met visschen, waarna hij zich wilde verwijderen. Hij riep Anansi herhaaldelijk om weg te gaan, maar deze beweerde telkens, dat hij bijna geen visschen gevangen had. Ongeduldig zeide Lantaarndrager, dat de $\mathrm{mama}$ (moedergeest) van het vischgat verstoord op hen worden zou, als zij er nog langer vertoefden. Doch Anansi lachte om die gekheid en verklaarde ronduit, dat hij niet van daar vertrekken zou, eer zijn korf vol visschen was. Toen werd Lantaarndrager boos, hing zijn korfje visch aan den schouder en aanvaardde alleen den terugtocht.

$\mathrm{Ba}$ Anansi zou de plaats zonder Mat Lantaarndragers hulp niet kunnen verlaten in de duisternis, waarom hij er tot het aanbreken van den dag bleef visschen. Mat Lantaarndrager had hem niet gezegd, dat het vischgat aan Ba Sjin-Sjin (Broer Beslagruimte vlieg) toebehoorde, die niemand daarin wou toelaten, omdat hij er dagelijks zelf hengelde. Anansi schrok hevig, toen Sjin-Sjin plotseling verscheen en hem driftig vroeg: "hoe kom je hier in 't vischgat? Weet je niet, dat 't van mij is? W'ie geeft je het recht mijn visschen te vangen? Wil je zien, dat ik je straf?»

Daarop antwoordde Ba Anansi: "Mat Lantaarndrager heeft mij hierheen gebracht, Ba Sjin-Sjin. Hij verzekerde mij, dat 't vischgat aan niemand toebehoorde en dat ik er vrij mocht visschen. Je moet mij niet straffen, want ik ben misleid geworden. De ware schuldige is Lantaarndrager, die hier om de twee vooravonden komt visschen. Je kunt er stilletjes de wacht houden en zult hem secuur op heeterdaad betrappen. Neem om Godswil niet al de visschen in beslag, die ik gevangen heb, doch laat mij de helft daarvan behouden. Ik heb een groote familie en wij hebben in lang geen stuk toespijs gegeten.» Sjin-Sjin zette ook de helft der visschen in zijn eigen korf en stond hem toe huiswaarts te keeren met de rest.

Niets kwaads vermoedende, ging Mat Lantaarndrager twee avonden later weer naar 't vischgat, waar Ba Sjin-Sjin uit 't struikgewas te voorschijn sprong en hem woedend aanviel. SjinSjin ranselde den vischdief met een stok af, totdat diens rug er bijna van brak.

Lantaarndrager boog zijn lichaam herhaaldelijk achterover, zichzelf telkens krachtig uitrekkende, waardoor hij een eindje naar omhoog wipte en er ten slotte met uitgedoofde lichten doodstil bleef liggen. Zoodra het gevaar geweken was stond hij op en ging naar huis. Maar hij herhaalde zijn vreemdsoortige beweging 
uit vrees voor een tweede pak slagen bij de minste aanraking, waarom die eindelijk zijn meest eigenaardige gewoonte werd.

$$
\begin{aligned}
& \text { XI. Hoe Ba Tigri's (Broer Tijgers) huid } \\
& \text { gevlekt werd. }
\end{aligned}
$$

Eer tien tien, Ba Anansi oefende het smidsberoep uit en kreeg veel meer werk van de blanken, dan de andere smeden. Men kon zich dat niet begrijpen, want hij was de grootste knoeier van allen. Niemand wist, dat hij door middel van een bakrahopo (blanken-bekoring) zooveel werk bekwam en er dus nooit gebrek dan hebben zou. Hij behoefde slechts tegen het fleschje met de bakra hopo te zeggen: "kroemoetoekoe, mibatra, gi $\mathrm{mi}$, san mi wani (kroemoetoekoe mijn flesch, geef mij wat ik wil)!, en de blanken stuurden hem onmiddellijk een massa karweitjes. Geheel bekoord, accepteerden zij met genoegen al het knoeiwerk van zijn hand. Het ging $\mathrm{Ba}$ Anansi zoo goed, dat de meeste mannen uit den omtrek speciaal bij hem wilden komen werken, maar hij vreesde zijn geheim te verraden en nam geen hunner in dienst.

Ook $\mathrm{Ba}$ Tigri hoorde van den voortvarenden smid Anansi spreken en kwam dezen verzoeken hem met het oog op de benarde tijden te leeren smeden. Anansi durfde Tigri zoo'n kleinigheid niet weigeren, doch achtte zich in diens bijzijn volstrekt niet veilig. Hij moest maken, dat de geweldenaar van diens voornemen afzag. Voorloopig sprak hij uiterst vriendelijk met hem. $\mathrm{Hij}$ wou Ba Tigri van harte gaarne leeren smeden. Zijn goed oe $\mathrm{Ba}$ (dierbare Broer) zou nog de beste smid ter wereld worden. Hij kon morgenochtend vroeg op het werk komen.

Den volgenden morgen verscheen $\mathrm{Ba}$ Tigri bijtijds in de smederij waar Ba Anansi terstond een stuk ijzer voor hem op 't aanbeeld legde, zeggende: "houd dit stuk ijzer stevig met beide handen vast en steek je voeten onder het aanbeeld, opdat het niet kan waggelen, als ik er op hamer.: Toen greep de smidsbaas vlug zijn grootsten moker en deed daarmee opzettelijk een geweldigen misslag. De zware moker verbrijzelde Tigri's handen, terwijl zijn voeten door 't aanbeeld platgedrukt werden. Brullend van pijn, viel hij op den grond, maar rees dadelijk weer overeind en hinkte naar huis. Ba Anansi dacht, dat zijn leerling voorgoed wegblijven zou, doch hij vergiste zich deerlijk.

Eenige weken later kwam Ba Tigri op zijn werkplaats, alsof 
er niets gebeurd was. Hij had zijn gewonde handen en voeten genezen, maar ze waren in vier pooten met vier klauwen veranderd. Natuurlijk kon hij minder goed werken dan vroeger en de dingen niet zoo stevig meer vasthouden. Ba Anansi verzocht hem om een grooten pot vol gesmolten lood van uit de hoogte in een vorm op den grond te gieten. Tigri hief den zwaren pot omhoog, die echter aan zijn klauwen ontglipte, waardoor het gloeiende lood op hem viel en langs zijn lichaam naar beneden vloeide. Luid brullende, rolde hij zich over den koelen grond, tot de brandende pijn bedaard was. Toen stond hij op en verliet de smederij, om er nimmer terug te keeren. Thuis genas hij binnen korten tijd van zijn vreeselijke brandwonden, die evenwel vele litteekens op zijn huid achterlieten in den vorm van donkere vlekken.

Zoo werd Ba Tigri's huid gevlekt, gelijk deze thans nog is.

XII. Ba Anansi en de Boesi-Papa (Boschvader) met het gelaat aan $z$ ij $n$ bovenkop.

Eer tien tien, Ba Anansi kwam, door het bosch loopende, toevallig in het kamp van een reusachtig grooten Boesi-papa, wiens aangezicht ter plaatse van zijn schedel was. Deze vreemdsoortige boschgeest keek voortdurend naar den heuvel, dus zag hij niet, wat er op de aarde om hem gebeurde. Ba Anansi bleef ongemerkt het avondmaal met Boesi-papa gebruiken, hetwelk uit een bos bananen en een vette kip bestond. Met grooten eetlust werkte Anansi zooveel voedsel naar binnen, dat de zonderlinge man slechts een halve portie kreeg. Deze moest zich hongerig ter ruste begeven, terwijl zijn dischgenoot met een vollen buik wegsloop.

Den volgenden avond maakte de Boesi-papa zoowat anderhalf bos bananen en twee kippen. klaar maar at zijn bekomst toch niet, want $\mathrm{Ba}$ Anansi smulde weer stilletjes mee en ditmaal in gezelschap van zijn gulzigsten zoon. Zoo vergrootte het bovennatuurlijke wezen zijn avondmaal geregeld, doch kwam Ba Anansi iederen keer met hem soupeeren en bracht telkens nog één zijner vraatzuchtige kinderen ten eten. Het aantal eters werd steeds grooter, dus leed Boesi-papa voortdurend honger. Hij vermoedde onraad en luisterde met toenemende aandacht naar elk geluid maar ontdekte de ongenoodigde gasten niet.

$\mathrm{Ba}$ Anansi geleidde ten slotte zijn vrouw Sa Jata aan tafel, 
die met hem en de kinderen over het eten begon te kibbelen. Op het hooren daarvan keerde Boesi-papa zich om en greep zijn langen dikken stok. Verschrikt vluchtten Sa Jata en de kinderen naar alle richtingen, maar op het geluid afgaande, zwaaide hij snel den stok in het rond en sloeg hen zonder genade dood.

$\mathrm{Ba}$ Anansi had zich languit op den grond geworpen, waar hij doodstil bleef liggen. Toen het gevaar voorbij was, sprong hij op en verliet de plaats. Hij durfde niet naar zijn woning terugkeeren, want de heuvelschouwer zou er hem misschien zoeken. Geen huis meer hebbende, achtte Ba Anansi het onnoodig een ander te bouwen, waarom hij in de post'oro kroop, die hij tot heden nog bewoont.

XIII. Zoekoe Troli.

(Ruzie zoeken).

Eer tien tien, Mat Koni-koni (Vriend Agoeti) had nog nooit met iemand getwist en zou gaarne willen weten, wat men toch ruzie noemde. Al Koni-koni's kennissen beantwoordden zijn vraag om inlichting ontwijkend, behalve Ba Anansi. Deze zou Mat Koni-koni des morgens vroeg bij Ma Tigri (mamatje Tijgerin) brengen, waar hij gemakkelijk de hevigste ruzie kon stoken. Koni-koni moest hem bijtijds wakker maken, omdat Ma Tigri diep in 't bosch woonde en zich tegen zonsopgang ter ruste legde.

Lang voor het aanbreken van den dag stond Mat Koni-koni op en wekte Ba Anansi. Beiden begaven zich naar de woonplaats van Ma Tigri, wier kinderen er over den grond kropen. Ba Anansi nam een daarvan op en wenkte Mat Koni-koni om hetzelfde met het andere te doen. Toen sprak hij tot zijn vriend: «zoodra ik uitroep: kwiensi (druk)!, dan drukken wij tegelijk de kleine tijgers in onze armen dood.» De ruziezoeker vond het goed en $\mathrm{Ba}$ Anansi gaf het sein. Hierbij wendde bij voor het tijgertje in zijn armen te verstikken, waardoor Mat Koni-koni misleid, er het andere werkelijk dood perste. Ter zelfder tijd verscheen Ma Tigri brullend aan den ingang van haar hol en vestigde een wantrouwenden blik op 't tweetal. Ba Anansi trad haar onmiddellijk met het levende kleintje tegemoet, zeggende: «ik passeerde zooeven hier, Ma Tigri, en hoorde je kind huilen. Daarom kwam ik binnen, om het een beetje voor je te sussen. Zie eens hoe rustig het is,» Ma Tigri nam haar jong uit zijn 
handen, waarna ze zich tot Mat Koni-koni wendde. Deze keek angstig rond, want hij durfde het vermoorde kind niet aan de moeder teruggeven. Plotseling sprong hij zijwaarts, liet het lijkje op den grond vallen en snelde langs haar heen naar buiten.

De vluchtende Koni-koni bereikte veilig een dichtbegroeid plekje, waar hij vlug een gat groef en zich daarin verborg. Ma Tigri ontdekte spoedig zijn schuilplaats, maar kon er hem niet uithalen. Daar ging Mat Hagoe (Vriend Varken) voorbij, dien zij op aanraden van Ba Anansi te hulp riep. Mat Hagoe kende het delversberoep en begon het gat dadelijk wijder te maken. Terwijl hij hiermede bezig was, sloop Ba Anansi stilletjes weg en keerde even later met wat pepervruchten terug. Hij schoof Mat Hagoe ter zijde, plaatste zijn mond voor het gat en vroeg Mat Koni-koni, of dit diep genoeg was. Koni-koni antwoordde ontkennend, waarop Ba Anansi er de pepervruchten ongemerkt voor zijn beschermeling gooide en hem tevens iets toefluisterde.

Als Mat Hagoe weer eens in het gat keek, spoog Mat Konikoni hem onverwacht een mondvol gekauwde peper in de oogen. Gillend van pijn, sprong Hagoe achterwaarts en liet de stukjes peper door Ma Tigri uit zijn oogen blazen. Deze kreeg zoodoende wat varkens oogwater in den mond, waarom zij watertandend sprak: "je oogwater is erg lekker, Mat Hagoe, dus zal je vleesch zeker overheerlijk zijn.» Hierop zeide Ba Anansi knipoogend: "wat je aanraakt, mamaatje, dat heb je reeds, doch wat in 't gat zit, is nog niet van jou., Ma Tigri begreep dezen wenk en verscheurde Mat Hagoe met haar geweldige klauwen. Zij vrat bijna al Hagoe's vleesch op en gaf $\mathrm{Ba}$ Anansi slechts het resteerende voor zijn goeden raad. Toen snelde zij voldaan naar huis, om haar hongerig jong te zogen.

Nadat Ma Tigri heengegaan was, kon Mat Koni-koni gerust uit 't gat komen, maar vreesde zoo vcor haar wraak, dat hij er levenslang bleef wonen en zwoer nooit weer ruzie met anderen te zullen zoeken. Daarom bewoont Koni-koni holen in den grond, waarheen hij voor de loerende Tigri's vlucht.

$$
\begin{gathered}
\text { XIV. Tara Poptji. } \\
\text { (Kleefpop.) }
\end{gathered}
$$

Eer tien tien, Ba Anansi wilde niet voor zijn dagelijksch brood werken, maar onderhield zich zelf, zijn vrouw Kwasita en drie kinderen met dieverij. Hij stal geregeld groote hoeveel- 
heden bananen in den gouvernements tuin, waarom bekwame politieagenten er voortdurend de wacht hielden. Doch zij konden den dief niet pakken omdat deze te slim voor hen was, hetgeen den gouverneur zeer verdroot. Hij liet heimelijk een met tara (kleefstof) besmeerden man of tarapoptji maken en dien in een afgelegen dicht begroeid hoekje van den tuin plaatsen. Daar zou de dief waarschijnlijk langs gaan en misschien ook in aanraking komen met het kleverige heerschap.

Als gewoonlijk, ging $\mathrm{Ba}$ Anansi tegen middernacht op den bananenroof in den gouvernementstuin, waar hij eensklaps voor de tarapoptji stond. Hij deinsde verschrikt achteruit, verward groetende: "dag meneer», waarop het levenlooze toestel natuurlijk niet kon antwoorden. Gerustgesteld, trad Ba Anansi weer nader en sloeg de tarapoptji met de hand op diens borst, vragende: "waarom antwoord je me niet?» Hierdoor kleefde zijn eene hand aan het ding vast, dat hij met de andere wilde wegduwen, gebiedende: "laat mijn hand los schurk?, Doch zijn vrije hand bleef er ook aan vast, hetgeen hem niet weinig ontstelde. Hij trachtte den vermeenden man eerst met den eenen en daarna met den anderen voet van zich af te schoppen, hem telkens dreigend gebiedende: "laat $\mathrm{mij}$ los, hoor, of ik roep den gouverneur. Instede van te gehoorzamen plakte de kleverige vent terstond beide voeten aan de zijnen vast, waarom Ba Anansi met zijn hoofd tegen diens buik stiet, dreigende: «als je mij niet los laat, zal ik je bij de politie aanklagen!» De tarapoptii pakte Anansi's hoofd beet, zoodat de schelm niet meer in staat was zich te verroeren. Deze smeekte zijn vanger om hem los te laten, maar de kleefpop bleef doof voor zijn beden en deed het niet.

Des morgens verscheen de politie ter plaatse en nam er Ba Anansi gevangen. De rechters veroordeelden den dief met goedkeuring van den gouverneur, om aan de galg te sterven, welk rechtvaardig vonnis voor zonsondergang voltrokken zou worden. Als een laatste gunst stond men toe, dat hij thuis afscheid zou nemen van zijn familie.

Ba Anansi vroeg zijn twee oudste kinderen beurtelings, hoe zij bij de terechtstelling van zijn persoon gingen huilen, waarop het antwoord van elk hunner klonk: «Papa Anansi voevoeroe bana gi oenoe na grammandjari (Papa Anansi heeft bananen voor ons gestolen in den gouvernements tuin.) Effe 
dem kiri Anansi, soema de go voevoeroe bana gi o en moro (Als zij Anansi vermoorden wie zal dan meer bananen voor ons stelen)? Hij duwde hen gramstorig ter zijde, want zij bevestigden den diefstal met hun gejammer en bekrachtigden zoo het doodvonnis. Wrevelig zocht Anansi naar zijn jongsten zoon, die aan yaws (framboesia) leed en hem daarom minder dierbaar was. Hij schopte het knaapje uit een donkeren hoek te voorschijn en deed hem ook dezelfde vraag. De kleine yawslijder antwoordde, dat hij niet huilen, doch het volgende gebedje zingen zou:

«Dem kiri Anansi, teh!

(Zij doodden Anansi, teh!)

Da heeli kondre sa soengoe (Het geheele land zal zinken).

Alla soema sa dede

(Alle menschen zullen sterven).

Gramman srefi sa krapeer toe

(De gouverneur zelf zal ook omkonen).

Anansi wawan sa tan

(Ba Anansi alleen zal blijven).,

Ba Anansi omhelsde het zieke jongske voor 't eerst van zijn leven en fluisterde verheugd: «jij bent een echte kleine Anansi. Jou moet ik hebben. Verberg je in den top van den grooten boom naast de galg en zing er herhaaldelijk je liedje, zoodra de strop om mijn hals gelegd is. Je zult er zeker mijn leven mee redden.» Hierna zeide hij al zijn familieleden vaarwel en werd door de politie naar het gouvernementsplein gevoerd, waar de terechtstelling zou plaats vinden.

Een groote menigte had zich om de galg verzameld, onder welke Ba Anansi stond, om wiens hals de gouverneur eigenhandig de strop legde. Nauwelijks was zulks geschied, of het bekende gezang weerklonk onheilspellend van den hoogen boomtop, alsof het uit den hemel kwam. Ba Anansi vestigde er de aandacht van de omstanders op, zeggende: "luister jelui naar het lied des Heeren!» En hij vertaalde het letterlijk voor den gouverneur. Allen schrokken hevig en de gouverneur schonk Anansi onmiddellijk gratie, die vroolijk naar huis ging.

Ba Anansi genas zijn zoontje van de yaws en behandelde het als zijn lieveling. 
XV. Ba Anansi en de Eénbeenige Boesi-Mama (Boschmoeder).

Eer tien tien, Ba Anansi voerde niets uit en zijn vrouw Sa Akoeba kon hem onmogelijk onderhouden. Akoeba gaf den gulzigaard net genoeg te eten, om hem in leven te houden, want zij moest drie kinderen behoorlijk voeden. Hij had voortdurend honger en dit akelig gevoel maakte hem diep ongelukkig. Klagend liep hij in huis rond, maar Akoeba stoorde zich daaraan niet. $Z$ ij zeide, dat hij blij mocht wezen, met wat hij van haar kreeg. De meeste vrouwen zetten hun luie mannen eenvoudig op straat. Alleen werkzame lieden hadden recht op goed eten. Als hij niet tevreden was met haar, stond de deur voor hem open.

Op een morgen zat Ba Anansi onder een grooten kankantrie-boom in 't bosch te schreien van verdriet, toen hij een schel gefluit in de verte hoorde en een vreemdsoortig wezen met recht overeind staande haren zag aankomen. Het was de Boesi-Mama, die op één been ronddraaiende, als een tol, bliksemsnel naderde. In een oogwenk stond Boesi-Mama voor hem stil, waardoor het gefluit van den wind om haar lichaam ophield, terwijl de lange losse haren over haar gelaat vielen en het bedekte, als een sluier. Zij vroeg naar de oorzaak van zijn leed en hij stortte zijn hart voor haar uit. Diep getroffen, draaide Boesi-Mama langzaam voort en wenkte Anansi om haar te volgen. $\mathrm{Zij}$ geleidde hem naar een wonderbaren boom in den omtrek, waarvan de takken beladen waren met zakken vol eten en sprak: «je moogt dagelijks drie zakken eten van dezen boom afslaan. Daaraan heb je ruim genoeg, dus zal je geen honger meer lijden. Meer dan drie zakken moet je nooit van den boom trachten te nemen, anders geraken zijn produkten bij tooverslag op». Toen verdween Boesi-Mama even snel, als zij verschenen was.

Ba Anansi nam drie kroisi-tiki's (werpstokken) onder den wonderboom zelf, met welke voorwerpen hij ook het bepaalde aantal zakken van dezen afsloeg. De eerste zak bevatte een smakelijk ontbijt; de tweede een lekker middagmaal en de derde heerlijk avondeten. Anansi droeg de drie zakken kost onder den arm naar huis, waar hij met veel lawaai binnentrad en alles voor zich op tafel plaatste. Hij zou de lekkere spijzen opsmullen en zijn familie met genoegen de vuile borden laten schoonlikken. Maar het ging anders toe, dan Ba Anansi gedacht had. Zijn 
vrouw en kinderen verslonden letterlijk het voedsel, waarvan hij slechts een klein beetje te eten kreeg.

Op dergelijke wijze aten Sa Akoeba en de kinderen telkens zooveel van de afgeslagen zakken eten, dat er bijna niets voor Ba Anansi overbleef, hetgeen hem zeer ontstemde. Hij bracht eindelijk geen voedsel meer thuis, doch at het onder den wonderboom op en makkte hen wijs, dat de voorraad daarvan geheel uitgeput was. Akoeba geloofde Anansi niet, want hij liet geregeld zijn bordje eten staan, en werd toch steeds dikker. Zij liet hem op een morgen stilletjes door de kinderen nagaan en deze zagen, hoe hij de zakken eten van den wonderboom afsloeg. Aanstonds sprongen allen te voorschijn, grepen de gevulde zakken snelden hiermee naar hun moeder. Ba Anansi zette de kinderen achterna, doch kon hen niet pakken. Dien dag leed hij ook honger, want Akoeba en de kinderen smulden weer al het eten op.

Met een groote mand op het hoofd vergezelde Sa Akoeba des ochtends vroeg haar kinderen naar den wonderboom. De kinderen sloegen er gemakkelijk drie zakken kost af, doch zij was met dit aantal niet tevreden en wilde meer hebben. Haar oudste zoon beproefde den boom te beklimmen, tengevolge waarvan deze meteen al zijn zakken wegtooverde, zelfs die reeds op den grond lagen. De gulzige vrouw en de kinderen verlieten onvoldaan het woud en ontmoetten Ba Anansi op weg daarheen. Hij begaf zich naar den wonderboom, om er zijn dagelijksch eten te zoeken, maar vond het niet en begreep terstond, wat er gebeurd was.

Ba Anansi ging onder den grooten kankantrie zitten weenen van teleurstelling. Boesi-Mama kwam weer vragen, wat er aan scheelde en hij vertelde haar ook alles en nog wat. Op 't hooren hiervan schudde zij bedenkelijk het hoofd, maar gaf hem toch een njanjam-krabasi (eetkalebas, of kalebas eetschaal), zeggende: *dit stuk kalebas is met obia (zwarte kunst) bewerkt en zal je driemaal 's daags spijzigen. Je behoeft het slechts te gebieden om je te geven wat je lust en je zult dat zeker krijgen. Doch je moet de kalebas na elk maal schoon wasschen, anders zul je er geen genot meer van hebben». Hierna ijlde Boesi-Mama fluitend weg, terwijl Anansi met de obia-kalebas huiswaarts keerde.

Ba Anansi kroop achter een groote kleerénkist in zijn woon- 
kamer, om daar heimelijk van zijn njanjam-krabasi te genieten. Hij gelastte dit voorwerp op gedempten toon: "nu krabasi, gi mi wan sureti fouroe-soepoe (mijn kalebas, geef mij een lekkere kippensoep)!» En de obia-schaal vulde zich bliksemsnel met genoemd gerecht. Ba Anansi deed zich aan de geurige soep te goed, wiesch zijn kalebas schoon en verborg haar zorgvuldig onder de etenskast. Vervolgens wandelde hij ongemerkt de deur uit, vast besloten niets van dit alles aan anderen te vertellen.

Anansi's dochtertje vond er bij het bezemen de njanjamkrabasi, die ze voor haar moeder bracht; Sa Akoeba plaatste de kalabas zoolang op tafel, tot Ba Anansi thuis kwam. Hij maakte daarover een verbazende drukte en verborg zijn eigendom op een veiliger plaats. Dit wekte den argwaan van Sa Akoeba op, die haar kinderen beval om zijn gangen nauwkeurig te bespieden.

Toen de kinderen eens verstoppertje speelden, zat het jongste bespiedertje toevallig in de groote kleerenkist, waarachter Ba Anansi kwam ontbijten. De knaap kon duidelijk verstaan, wat deze er zijn njanjam-krabasi gebood en hem tevens zien eten. Zoodra Anansi zich vandaar verwijderd had, sprong hij uit de kist, om zijn moeder in kennis te stellen met het gebeurde. Sa Akoeba legde beslag op de obia-kalebas, die zij precies zoo toesprak als Ba Anansi. De tooverschaal bracht dan ook den verlangden kost voort dien Akoeba eerlijk met de kinderen deelde. Na den maaltijd echter eischte zij nog een portie eten van de ongewasschen kalebas, waardoor deze onmiddellijk alle tooverkracht verloor en niets meer vermocht voort te brengen.

Bij zijn terugkomst zag Anansi de bedorven kalebas op den vloer liggen, hetgeen hem zeer driftig maakte. Hij trapte het waardelooze ding stuk en verliet zijn woning.

Huilend van woede, nam $\mathrm{Ba}$ Anansi onder den grooten kankantrie plaats, maar Boesie-Mama sloeg er geen acht op. Ongeduldig wordend riep hij herhaaldelijk: "Boesi-Mama, BoesiMama, kom mij toch helpen!» Hierop kwam Boesi-Mama met woedend gefluit aan zetten. $\mathrm{Zij}$ zweepte Anansi met heur lange haren, tot hij van pijn flauw viel en spoedde zich weer tolsgewijs heen. Anansi herkreeg zijn bewijstzijn, doch wilde niets meer van zijn familie weten, door wier toedoen Boesi-Mama hem geslagen had. Hij verhuisde naar de post'oro, teneinde er voor altijd te blijven wonen. 
XVI. Ba Anansi's loopje met Mat Sieksijoeroe (Vriend Zesuur, of Cicade).

Eer tien tien, Ba Anansi sliep bij nacht, maar Mat Sieksijoeroe bij dag, waarom de eene soupeerde, terwijl de andere ontbeet, Zoodra Sieksijoeroe wakker werd, ging hij eens zien, hoe het Anansi ging. Hij vond hem geregeld aan tafel met een avondmaal van boschvisch voor zich. Ongevraagd nam hij dan naast zijn goedoe $\mathrm{Ba}$ plaats en at met hem mee.

Ba Anansi joeg Mat Sieksijoeroe liever niet weg, doch wilde zijn visch van hem terug hebben. Sieksijoeroe zou Anansi volgaarne de gewenschte schadevergoeding geven, maar wist niet, waar zooveel boschvisch vandaan te halen, omdat er zware regens vielen en 't bosch onder water stond. Ba Anansi besloot een loopje te nemen met dien ongemanierden luiaard en lichtte hem in, dat het nu juist tijd voor lowé-fisi (ontsnapte visschen) was, die uit de vischgaten gezwommen waren. Hij kende plaatsen, waar dergelijke visschen in grooten getale op den overstroomden grond voor het grijpen lagen. Mat Sieksijoeroe moest hem met zonsopgang daarheen vergezellen en zou er gemakkelijk een heeleboel verzamelen, eer het donker werd. Hij kon hem dan al zijn visschen teruggeven en toch genoeg voor zich zelf overhouden. Sieksijoeroe had er een hekel aan om den geheelen dag wakker te blijven, maar hield veel van visch en zou daarom met Anansi medegaan.

Als de dag aanbrak, vertrok Ba Anansi met zijn vischkorf van huis en ging Mat Sieksijoeroe afhalen. Hij bracht dezen diep in 't bosch en wees er hem slechts een klein vischje in een grooten plas water. Mat Sieksijoeroe was hierover zeer ontevreden en liet het duidelijk blijken. Ba Anansi verzekerde hem, dat het er daags te voren van visschen krioelde, die alle verdwenen waren. Mat Sieksijoeroe twijfelde eraan maar gaf den moed niet op.

$\mathrm{Ba}$ Anansi beloofde Mat Sieksijoeroe om hem naar een vischrijke plaats te brengen, instede waarvan hij langs een grooten omweg den terugtocht aanvaardde. Voortloopende, zag Sieksijoeroe vaak bekende voorwerpen, die verrieden dat zij langzaam den woudzoom naderden. Hij maakte er Ba Anansi telkens op attent, maar deze zong:

Dl. 82. 
"pe mi waka kaba, mi no de waka moro

(waar ik al geloopen heb, loop ik niet meer)

ma pe mi de go, boen»

(maar waar ik ga, is goed).

Eindelijk bereikten zij weer den ingang van 't bosch, tot groote ergernis -van Mat Sieksijoeroe, die begreep, dat Ba Anansi een loopje met hem genomen had. Hij zou zijn voet niet meer in Anansi's huis zetten, dus was deze bevrijd van zijn ongenoodigden gast.

\section{Ba Anansi en de Tigri-Mama (Tijgermoeder).}

Eer tien tien, Ba Anansi bevond zich op jacht in 't oerwoud en schoot er een grooten a n a moen (tinamoe). Met dezen vogel huiswaarts keerende, ging hij toevallig langs een open plek, waar een groote hut stond. Daar woonde Tigri-mama, die bij 't vuur zat en een pot water kookte. Ba Anansi bemerkte, dat zij er vele varkens op na hield in een groot hok achter de hut, en wilde deze dieren van haar zien te krijgen. Aanstonds trad hij nader en groette met een kosie (kniebuiging): "dag Mamaatje!» Tigri-mama beantwoordde zijn groet vriendelijk: »dag mijn kind», terwijl ze met begeerige blikken naar de an amoen in zijn hand keek. Zulks ontging Anansi niet en hij verzocht haar eerbiedig: "Tangi, tangi Mamatje (dankje, dankje mamaatje), maak de an a moen voor mij klaar. Ik heb den vogel van morgen vroeg geschoten en woon zeer ver van hier. Zijn vleesch zal zeker bederven voordat ik 's avonds thuis kom. Tigrimama nam den anamoen, die ze in den pot met water deed.

Toen de anamoen op vuur stond, zeide Ba Anansi, dat hij straks zou komen 'eten en verwijderde zich. De leeperd wist, dat Tigri-mama graag anamoen-vleesch lustte, dus hoogst waarschijnlijk te veel van het zijne proeven zou, in geval hij lang genoeg op zich liet wachten. En werkelijk had Tigri-mama reeds de helft van zijn a n a moen opgepeuzeld, toen hij hierom kwam vragen. De oude vrouw meende er recht op te hebben, want zij had den vogel klaar gemaakt. "Had ik je a namoen niet gekookt», sprak zij, "dan zou je er nooit een stuk van eten». Maar Ba Anansi beweerde, dat zij misbruik van vertrouwen gepleegd had. "Wat je gedaan hebt, moedroe (moedertje), zeide hij, "staat gelijk aan diefstal. Je moet mij wekelijks een 
varken geven als schadeloosstelling voor dien halven a n a moen, anders laat ik je door de politie oppakken en wordt je gestraft." Terwille van haar vrijheid, besloot Tigri-mama aan zijn eisch te voldoen en stopte meteen het eerste weekvarken in den vervoerzak. Ba Anansi nam den zak met het varken, dat hij op zijn rug wegdroeg.

Zoo ging $\mathrm{Ba}$ Anansi geregeld zijn weekvarken bij Tigri-mama halen tot deze er slechts één over had. Hem ook in 't bezit hiervan stellende, sprak zij: «ik heb je reeds al mijn varkens gegeven voor je stuk an amoen. Ik heb er geen meer en kan die van anderen niet voor je stelen. Wees dus tevreden en laat mij nu met rust., Maar Ba Anansi schudde driftig het hoofd, zeggende: « je moet voor je vraatzucht boeten. Het kan me niet schelen, hoe je aan meer varkens komt, maar ik moet het mijne geregeld hebben, anders maak ik van mijn recht gebruik en laat je opsluiten.» Hierna vertrok Anansi met Tigri-mama's laatste varken op den rug.

Teneinde raad, makkte Tigri-mama reeds toebereidselen om te vluchten, toen haar geweldige zoon Ba Tigri uit de binnenlanden terug keerde. $\mathrm{Zij}$ stelde hem in kennis met het gebeurde, waarop hij toornig brulde: «je moet mij in den zak doen en zoo in.' $t$ varkenshok leggen. Ba Anansi zal niet weten, wie in den zak is, dus dezen eveneens naar huis dragen, waar ik te voorschijn spring en hem verscheur.» Tigri-mama keurde het plan goed en zou hem bij de volvoering hiervan behulpzaam zijn.

Op den bepaalden dag kreeg $\mathrm{Ba}$ Anansi weer zijn varken van Tigri-mama, dat hij ook in den zak op zijn rug huiswaarts droeg. Onderweg echter drongen Ba Tigri's scherpe nagels door den zak heen en krabden hem zeer gevoelig. Daar geen varken klauwen heeft, begreep hij meteen, dat Tigri voor genoemd dier speelde. Ba. Anansi waagde het niet den geweldenaar op den weg te laten liggen, vreezende, dat die den versleten zak open zou scheuren en hem vermoorden. Maar hij durfde zijn vracht ook niet thuis brengen, want dat was even gevaarlijk. Besluiteloos stond hij stil en keek overal rond. Hij riep zijn buurman Koni-koni, die er voorbijging, en fluisterde hem in 't oor: "breng het varken in dezen zak naar huis, Mat Koni-koni, en slacht het voor mij. Je moogt er een geheelen achterbout van hebben. Ik ga eenige vrienden ten eten uitnoodigen en kom straks.» Koni-koni nam den zak en Anansi verwijderde zich. 
Mat Koni-koni sleepte den zwaren zak naar Ba Anansi's woning, waar Ba Tigri er brullend uitsprong. Doodelijk ontsteld viel Konikoni voor hem op de knieën en smeekte hem om zijn leven. «Ik heb je buiten mijn weten hierheen gebracht, Ba Tigri», verzekerde hij stellig, "want $\mathrm{Ba}$ Anansi maakte mij wijs, dat er een varken ir den zak was. Je kunt hem gaan vragen, of het niet waar is. $\mathrm{Hij}$ is zeker weer in het naast bijgelegen vischgat aan het werk.» Op het hooren hiervan snelde Tigri er heen.

Onderwijl was Ba Anansi waarlijk in dat vischgat afgedaald, waar hij naar visschen rondtastte. Hij ontdekte spoedig een groot vischhol en stak er argeloos de hand in. Deze werd terstond door een onzichtbaar wezen gegrepen, dat hem naar zich toe trok. Ba Anansi beproefde vergeefs zijn hand los te rukken, waarom hij angstig vroeg: *wat voor mensch houdt er toch mijn hand vasst? Hierop ontving hij van het ding in het hol ten antwoord: «ik ben geen mensch». Toen vroeg Anansi verschrikt: "wat ben je dan?" waarop het antwoord luidde: «ik ben Adoe (Doener)». Dat verbaasde Anansi, die uitriep: "doe dan, opdat ik zie, wat je kunt doen!, Adoe slingerde hem van zich af, zoodat hij de lucht invloog en met zijn buik op het modderige boschpad terecht kwam. Ba Anansi stond ongedeerd op, waarna hij zich andermaal door Adoe naar omhoog liet werpen. Hij viel op dezelfde plaats neer en plantte er een scherp toegespitste staaf in den grond. Voldaan hierover, ging hij weer in 't vischgat en hervatte er zijn werk.

Terwijl Ba Anansi aan het visschen was, verscheen Ba Tigri in de verte, zeer kwaadaardig brullende. Tigri mama's zoon had zijn woede niet aan Mat Koni-koni gekoeld, maar kwam zich op den waren schuldige wreken. Ba Anansi pakte gauw wat visschen en wierp deze voor hem op 't droge. "Proef eens, Ba Tigri», sprak hij, "welke heerlijke visschen hier voor 't grijpen liggen». $\mathrm{Nu}$ was $\mathrm{Ba}$ Tigri dol op boschvisschen, dus kon hij de verleiding niet weerstaan en at die van Anansi smakelijk op. De lekkere visch stemde hem vriendelijk jegens den milden gever, die hem Adoe's verblijfplaats wees, met de woorden: 'steek je hand in dit hol en je zult er een massa visschen vinden.»

Ba Tigri lustte meer visch, waarom hij te water sprong en de hand in het aangewezen hol stak. Adoe pakte er zijn hand beet en trok hem met geweld neer. Op Anansi's advies richtte $\mathrm{Ba}$ Tigri terstond de bestemde vragen tot het bovennatuurlijke 
wezen, op welks antwoord: «ik ben Adoe», hij eveneens moest uitroepen: "Doe dan, opdat ik zie, wat je kunt doen!» Het gevolg hiervan was, dat Tigri door Adoe in de hoogte gesmeten werd en op Anansi's puntige staaf neerkwam. Ba Anansi nam $\mathrm{Ba}$ Tigri's doorboord lichaam van de staaf en vervoerde het naar huis. Die geheele week at hij tijger- in plaats van varkensvleesch.

Toen Tigri-mama hoorde wat $\mathrm{Ba}$ Tigri overkomen was, stierf zij van verdriet, dus kon $\mathrm{Ba}$ Anansi natuurlijk geen varkens meer van haar krijgen. Doch hij stelde Adoe geregeld te werk, die velen dieren op zijn staaf wierp en hem zoo een massa vleesch bezorgde.

XVIII. Ba Anansi's ondrowatra-pennitji's (Staven onder water).

Eer tien tien, Ba Anansi had een groot vischgat ontdekt, waarin hij dikwijls hengelde. Maar de visschen wilden er niet bijten, dus ving hij nooit veel. Op een middag keerde hij weer met een paar visschen in zijn korf huiswaarts en ontmoette onderweg Mat Bofroe (Vriend Tapir). Wetende, hoe deze met nekoe (vischvergif) te werk ging, sprak hij tot hem: "ik kom zoo van een vischgat, Mat Bofroe, waar er zeer veel visschen zijn. Zweer dat je eerlijk met mij deelen zult wat je daar vangt, en ik breng je er heen.» Bofroe zwoer het en Ba Anansi bracht hem op dienzelfden dag naar 't vischgat.

Zonder dralen sprong Mat Bofroe in 't zwarte water en deponeerde er eenige van zijn met nekoe beladen hoopjes. Hij troebelde het water met zijn pooten, tot het giftige afval er geheel in opgelost was. Hierdoor bedwelmd, kwamen de visschen aan de wateroppervlakte drijven, waar zij door Bofroe gepakt werden. De gulzigaard vrat al de visschen op, zonder Anansi zelfs iets van zijn aandeel te geven en verwijderde zich met een volle maag.

$\mathrm{Nu}$ kon $\mathrm{Ba}$ Anansi ook niet meer in 't vischgat hengelen, daar Bofroe er het water geregeld vergiftigde. Hij moest dien giftmenger dus uit den weg ruimen en zoo mogelijk op een voordeelige manier.

Ba Anansi wilde Ma Aboma (Mamaatje Worgslang) in de gelegenheid stellen Mat Bofroe te verworgen, voor welken grooten dienst hij slechts de helft van diens vleesch verlangde. $Z$ ij vond 
het uitstekend en Anansi wees haar van welke plek Bofroe gewoonlijk in 't vischgat sprong. Ma Aboma kronkelde haar bovenlijf om een boomtak, waar zij met neerhangenden staart op den dikzak wachtte. Toen deze naderbij gekomen was, pakte zij hem bij den staart beet, doch hij trok haar lichaam stuk en ging heen.

Mat Bofroe zocht een open plek uit, vanwaar hij voortaan in het vischgat springen zou. Maar Ba Anansi sloeg den vischroover nauwkeurig gade en bemerkte, waar deze neerplonsde. Daar plantte hij onder water eenige toegespitste staven in den bodem, zoodat Mat Bofroe er bij den eerst volgenden sprong met zijn volle zwaarte op de scherpe punten terecht kwam. $\mathrm{Na}$ veel moeite haalde Ba Anansi Bofroe's doorpriemd lichaam op 't droge en sleepte het naar zijn woning. $Z$ ij smulden allen daarvan, hetgeen ruim een week duurde. Middelerwijl was het water in 't vischgat reeds zuiver geworden, dus kon hij er weer hengelen.

XIX. Boekfen, Boekfen!

Eer tien tien, Ba Anansi en Mat Koni-koni waren kostgrondburen van Masra Hontiman (Meneer Jager). Anansi bezat een grondje aan de eene zijde van Hontimans grooten kostgrond en Koni-koni had er een aan den anderen kant. De grondjes produceerden niet veel en dienden meer om anderen in den waan te brengen, dat de eigenaars daarvan eerlijk hun dagelijksch brood verdienden. Hontiman wist, dat er in zijn kostgrond gestolen werd, maar dacht niet, dat Anansi en Konikoni zoo iets zouden doen, want dezen beplantten hun eigen grondjes. Daarom probeerde hij vergeefs de dieven te pakken, die van hem zelf vernamen, welke pogingen hij daartoe in 't werk zou stellen.

Ba Anansi en Mat Koni-koni kenden elkanders kostgrond geheim, doch elk hunner meende, dat de andere niets van zijn misdrijf afwist. Nu vond Koni-koni, dat Anansi te veel van Hontiman stal en ten slotte diens verdenking niet alleen op zich zelf, maar ook op hem zou laten vallen. Aan Anansi's overmatig stelen moest dus een einde gemaakt worden en hij zou trachten het te doen.

Mat Koni-koni zag Anansi weer met een draagkorf in Hontimans kostgrond sluipen, terwijl hij er zelf aan 't stelen was. $\mathrm{Hij}$ deed eenige dwaze sprongen onder 't maken van een vreemd 
geluid, zoo: "boekfen, boefken». Hem voor een boozen geest aanziende, stal Ba Anansi niets, maar zette het op een loopen. Hetzelfde herhaalde zich verscheidene malen, tot Anansi, door honger gedreven, den boozen geest bespiedde en Koni-koni in dezen herkende.

Ba Anansi ging Masra Hontiman onmiddellijk vertellen, dat iemand bezig was zijn kostgrond leeg te plunderen. *Ik ging toevallig langs je kostgrond,» sprak hij, "en zag er den dief. Deze sprong in de hoogte, terwijl hij een raar geluid voortbracht, zoo: "boekfen, boekfen.» "Hij deed het zeker om mij bang te maken, opdat ik hem met rust zou laten.»

Hontiman nam zijn geweer en vergezelde Anansi naar den kostgrond.

Nabij zijn grond verschool Masra Hontiman zich achter een boom, terwijl Anansi voortsloop, alsof hij er wilde stelen. Op 't zien van Anansi sprong Mat Koni-koni weer de lucht in met dat akelige geluid, zoo: «boekfen, boekfen». Hontiman schoot den bangmaker met zijn geweer dood en trad vervolgens nader. Hij gaf $\mathrm{Ba}$ Anansi uit dankbaarheid de helft van Mat Konikoni's vleesch, alsook diens draagkorf met 't gestolen goed.

Vanaf dien tijd stal Ba Anansi dagelijks nog grootere hoeveelheden kostgrond produkten van Hontiman, want deze vertrouwde hem blind en geloofde, dat anderen het deden.

XX. Boen no habi Tangi.

(Ondank is 's werelds loon).

Eer tien tien, Mat Tingi-fowroe hielp Ba Anansi gratis een dood dier naar zijn woning slepen, en Anansi verklaarde zich uit dankbaarheid tot wederdienst bereid. Eenigen tijd later werd Tingi-fowroe door een hevigen dorst gekweld, maar kon nergens water vinden, om dien te lesschen. Toevallig ging hij langs 't werkhuis van $\mathrm{Ba}$ Anansi, die er zich met vrouw en kinderen bevond. Mat Tingi-fowroe groette hem aan de deur en verzocht: "tangi, tangi Ba Anansi, geef me een beetje water te drinken."

Ba Anansi had een kolossale kruik vol water, doch wilde niet, dat Tingi-fowroe met diens viezen bek uit zijn mok drinken zou en zeide: «ik heb geen water hier op mijn werkplaats, maar zal een mijner kinderen zenden, om het voor je te halen». Toen gebood hij met luider stem zijn jongste kind: "ga gauw een groote kan frisch regenwater thuis halen voor onzen weldoener 
Mat Tingi-fowroe!» doch voegde er in het $\mathrm{Kropina}{ }^{1}$ ) bij "on mok kaba (kom niet terug)». Het gehoorzame kind snelde weg, terwijl Tingi-fowroe, die geen $\mathrm{K}$ ro pin a kende, op zijn terugkomst bleef wachten.

$\mathrm{Na}$ een poos sprak Mat Tingi-fowroe zuchtend: ik ben vreeselijk dorstig, Ba Anansi. Waar blijft dat kind toch met het water?» Daarop antwoordde Ba Anansi: «dat weet ik zelf niet, Mat Tingifowroe. Maar ik zal een ander kind van mij naar hem laten zoeken.» En hij beval hardop een ander kind: "ga eens kijken, waar je broertje met 't water van Mat Tingi-fowroe zit!» Doch voegde er weer in 't Kropina bij: "on mok kaba!»

Zoo stuurde Ba Anansi al de overige kinderen weg, om voor den klagenden Mat Tingi-fowroe te gaan zien, waar de vorige met 't water bleven. Hij gelaste elk hunner tevens in 't Kropina: "on mok kaba" dus keerde er geen weder. Ook zijn vrouw, die hij met 't zelfde Kropina bevel uitzond, ter opsporing der kinderen, bleef weg.

Ten slotte zuchtte Mat Tingi-fowroe: «ik kan 't niet meer uithouden, Ba Anansi! Waar toeven je vrouw en kinderen zoo met 't water?" En Ba Anansi gaf hem ten antwoord: "Dat zal ik nu zien te weten te komen, Mat Tingi-fowroe." Anansi sloot de deur van 't werkhuisje en verwijderde zich met de belofte, dat hij er 't water straks voor zijn goeden vriend brengen zou.

Mat Tingi-fowroe wachtte een heelen tijd op Ba Anansi en begreep eindelijk, dat hij door dezen voor den gek gehouden was. Stervend van dorst, wilde hij verderop water gaan zoeken, maar kwam onderweg om.

Ba Anansi vertelde het geval aan iedereen, want hij vond het zeer grappig. Sommigen lachten erom, doch de meesten zeiden "boen no habi tangi." Alzoo ontstond dit Negerengelsch spreekwoord.

XXI. Konkroe nanga lei meki wisiman feni wroko. (Konkelarij en leugen lieten den giftmenger werkvinden).

Een tien tien, Ba Anansi was wisiman, maar had niets te doen, omdat er overal vrede op aarde heerschte. Konkelarij en leugen konden Anansi spoedig een grooter praktijk bezorgen

1) Kropina beteekent een boeventaal, waarbij de woorden omgekeerd worden uitgesproken, bijv. on/mok/kaba i.p. v. no kom baka $=$ kom niet terug. 
en hij wist het: Daarmee zou hij vrienden tot vijanden maken, die hem ongetwijfeld werk in overvloed geven zouden.

Ba Anansi zocht Pa Tigri op en sprak tot hem: «luister, Pa Tigri, wat Mat Sekrepatoe doet. Hij vertelt zooveel leelijke dingen van je, o.a. dat je op je kracht pocht, maar een lafaard bent en zelfs niet met hem durft vechten. Je kunt me gelooven, man.» Hierop brulde Tigri driftig: "dat is een beetje te erg van Sekrepatoe! Ik zal dien kwajongen doodslaan wanneer ik hem tegen kom.»

$\mathrm{Ba}$ Anansi gaf $\mathrm{Pa}$ Tigri groot gelijk, doch bracht diens bedreiging direkt aan Sekrepatoe over. "Je moet goed oppassen met jezelf, hoor, Mat Sekrepatoe,» zeide hij, "want Pa Tigri gaat je doodslaan, als hij je ziet. Op 't hooren hiervan riep Mat Sekrepatoe verschrikt uit: "maar ik heb Pa Tigri niets gedaan! Ik weet heusch niet wat te beginnen. Misschien is hij reeds op weg hierheen!, Toen fluisterde Anansi: "maak je niet ongerust Sekrepatoe. Ik zal je een fleschje feti-obia (obia d.i. middel om te vechten) geven, dat je in staat stelt Pa Tigri gemakkelijk af te ranselen. Je houdt het in de hand verborgen en slaat het op zijn voorhoofd stuk. Dan zul je zelf zien, hoe goed het werkt. Ik ga $\mathrm{Pa}$ Tigri straks verwittigen, dat je bij 't aanbreken van den dag met hem wilt vechten onder den grooten cederboom dichtbij de kreek. Vrees niet.» Anansi haalde een fleschje vol met in koesoewe (roucou) water geweekt brood uit zijn zak en overhandigde het aan Sekrepatoe. Hierna ging de ruziemaker naar $\mathrm{Pa}$ Tigri, dien hij mededeelde, waar, wanneer en hoe Sekrepatoe met hem wilde vechten.

Met zonsopgang verscheen $\mathrm{Pa}$ Tigri brullend onder den cederboom, waar Ba Anansi en Mat Sekrepatoe reeds op hem stonden te wachten. Anansi wees de vechters terstond hun plaats aan, die beiden onbevreesd innamen. Volgens de regels van 't gevecht zouden zij elkander beurtelings een vuistslag geven, tot een hunner er onder bezweek. Mat Sekrepatoe was kleiner dan $\mathrm{Pa}$ Tigri, en mocht hem derhalve eerst slaan. Hij hief de vuist met 't fleschje feti-obia erin op, zeggende: "Steek je kop meer naar voren, $\mathrm{Pa}$ Tigri, want ik wil dien met één slag verbrijzelen en mijn arm is een beetje kort. Tigri vreesde dien slag niet, dus deed hij gewillig, wat van hem verlangd werd. Toen sloeg Mat Sekrepatoe gauw het fleschje op zijn voorhoofd stuk, waardoor een gedeelte van 't fet i - obia eraan bleef vastkleven, terwijl de rest op den grond viel. 
Ba Anansi snelde dadelijk toe en wees op de roodgekleurde broodpap, uitroepende: «Zie eens hier, Pa Tigri, wat er gebeurd is, Mat Sekrepotoe heeft de hersenen uit je hoofd geslagen, man, dus behoef je niet meer te vechten. Houd je rustig hoor, want je zult spoedig sterven!» Doodelijk ontsteld keek Pa Tigri naar de roode massa en betastte zijn voorhoofd. Daar het hem volstrekt geen pijn deed, wilde hij zeker weten, of zijn einde nabij was.

Ba Anansi riep eenige kennissen, die er passeerden, o. a. Mat Koni-koni, Mat Pakira (Vriend Peccari), Omoe Bofroe (Oom Tapir) en Datra Dia (Dokter Hert), elk hunner tevens verzoekende Pa Tigri's hoofd voor hem te onderzoeken. Hij voegde er telkens bij: "Mat Sekrepatoe heeft de hersenen uit zijn hoofd geslagen, doch hij wil 't niet gelooven. $\mathrm{Nu}$ hielden genoemde voorbijgangers niet van den geweldenaar, waarom zij terugschreeuwden: "Hoe eerder hij sterft, hoe beter!» en haastig hun weg vervolgden.

Mat Kesi-kesi (Vriend Aap) had niets tegen Pa Tigri en kwam kijken of diens wonde levensgevaarlijk was. Maar hij kon 't niet uitmaken, zoolang de haartjes aan elkander vastgeplakt waren. Hij sprak dus: "Kom je hoofd in de kreek schoonwasschen, Pa Tigri.» Gevolgd door Anansi en Sekrepatoe ging Pa Tigri met Mat Kesi-kesi naar de kreek. Kesi-kesi wiesch de roode broodpap met wat kreekwater van Tigri's voorhoofd af en ontdekte natuurlijk het bedrog. Wetende, dat Tigri geen $\mathrm{K}$ ro pin a verstond, zeide hij in deze dieventaal tot zijn goeden vriend Sekrepatoe: "Zoodra ik schreeuw "water", moet je te water springen, anders ben je verloren.»

Plotseling greep Mat Kesi-kesi den laag neerhangenden tak van een nabij staanden boom, op welken hij vlug klauterde en het sein gaf. Mat Sekrepatoe sprong in de kreek, waarna Kesikesi luidkeels spotte: »weh Pa Tigri, weh, ze hebben je voor den gek gehouden! Wat je voor bloedige hersenen aangezien hebt, is niets anders dan wat brood in koesoewé water geweekt! Weh Pa Tigri, weh!» Intusschen was Ba Anansi in denzelfden boom geklommen als Kesi-kesi, en lachtte Tigri hartelijk uit. Deze keek van Kesi-kesi en Anansi in den boom naar Sekrepatoe in de kreek, doch kon geen van allen te pakken krijgen. Driftig brullende, keerde hij huiswaarts, maar zwoer zich op 't drietal te zullen wreken, vooral op Sekrepatoe.

Velen billijkten Pa Tigri's toorn, terwijl anderen zich openlijk 
aan de zijde van Mat Sekrepatoe en diens vrienden schaarden, hetgeen een hevige ruzie teweeg bracht. Hierdoor ontstonden bittere vijanden, die geregeld wisi's (giftige middelen) bij Anansi bestelden, om elkander kwaad te doen; dus kreeg hij van dien tijd af volop werk.

XXII. Hoe Ba Anansi met Bas Tigri (Baas

Tijger) afrekende.

Eer tien tien, Ba Anansi was Bas Tigri reeds lang een kleinigheid verschuldigd, maar wilde hem niet betalen. Hij hield zich voor zijn schuldeischer verborgen, of maakte hem wijs, dat i iij niet bij kas was. Eindelijk drong Tigri gramstorig de woning van Anansi binnen, wien hij dreigend om zijn geld vroeg. Doch Anansi smeekte hem nog wat geduld te oefenen, hij zou het volle bedrag over eenige dagen kunnen komen halen.

Op den bepaalden dag kwam Bas Tigri veel vroeger aanzetten, dan Anansi verwacht had. Deze had geen geld, om hem te geven, en kon het huis ook niet ongemerkt verlaten. Gauw kroop hij in een groote $\mathrm{krabasi-godo}$ en liet het deksel achter zich dichtvallen. Onmiddellijk hierna brulde Bas Tigri buiten: "Is er niemand thuis?" Geen antwoord krijgende, stiet hij eenvoudig de deur open en trad binnen. Hij nam er de dichte godo, zeggende: «deze godo is juist zooveel waard, als ik van $\mathrm{Ba}$ Anansi hebben moet. Ik zal het ding inpalmen voor mijn geld., En hij verwijderde zich met de godo waarin Ba Anansi na een poosje uitriep: "Bas Tigri o h! Je moeder verdrinkt en $\mathrm{Ba}$ Anansi tracht haar te redden!» Anansi's stem klonk er zeer gedempt, zoodat het Tigri toescheen alsof die heelemaal van de rivier kwam. Hij zette de godo op den grond en snelde daarheen. Toen kroop Anansi weer uit de godo en bracht deze vlug naar huis.

Bas Tigri bereikte de rivier en keek deze op en af. Er was geen drenkeling, noch redder aanwezig, dus liep hij weer naar de plaats terug, waar de godo door hem achter gelaten was. De godo lag er niet meer, waarom Tigri met leege handen huiswaarts moest keeren.

Ba Anansi bezocht Tigri in zijn woning en sprak: «ik ben je komen betalen, Bas Tigri, maar verlang eerst de godo terug, die je thuis nam gedurende mijn afwezigheid.» Hierop zeide Bas Tigri dat de godo zoek geraakt was. Ba Anansi behield het aan 
Tigri verschuldigde geld en zijn verloren eigendom en rekende zoo met hem af.

\section{Man Bori \\ (Man is gekookt).}

Eer tien tien, Ba Anansi sprak op zekeren dag tot zijn vrouw: «Sa Akoeba ik heb niets te eten.» $\mathrm{Zij}$ snauwde hem toe: "dan zullen wij en de kinderen van honger sterven want ik bezit ook geen voedsel.». Hij verzekerde haar, dat zulks nooit gebeuren zou en ging de deur uit. Ba Anansi sloeg den weg naar 't bosch in en zag er Mat Koni-koni op een afstand voorbijgaan. Hij vroeg hem: "Mat Koni-koni, wil je niet een aardig spelletje van mij leeren?» Koni-koni wilde niets met den bedriegelijken Anansi te maken hebben, dus antwoordde hij zonder stil te staan: ik heb geen tijd daarvoor, Ba Anansi. Het eten is schaarsch in den kostgrond, en ik moet overal wat loopen zoeken om mijn buik te vullen.

Zoo vroeg Ba Anansi al de voetgangers, die hij ontmoette, o. a. Mat Hei (Vriend Pakka), Mat Piengo (Vriend Pingo), Mat Dia (Vriend Hert) en Mat Bofroe, of zij niet een aardig spelletje van hem wilden leeren, maar geen hunner gevoelde er lust toe. Allen wantrouwden Anansi, op wiens vraag zij, voortloopende, ten antwoord gaven, dat het geen tijd was voor spelen, doch om eten te zoeken. Slechts Mat Kesi-kesi naderde en zijn antwoord luidde: ja zeker Ba Anansi, ik wil je spelletje leeren. Maar zeg mij eerst, wat voor spel het is.

Ba Anansi deelde Mat Kesi-kesi mede: "mijn spelletje heet man bori. Ik leerde het van mijn besten vriend, die dezer dagen overleden is. Ik ben nu de eenige, die het spelletje kent, en moet dit aan een ander leeren vóór mijn dood, anders gaat het verloren.» Kesi-kesi vond, dat het jammer zou zijn van dat spelletje en vergezelde $\mathrm{Ba}$ Anansi direct naar diens woning, om er de eerste les van hem te nemen.

Thuis plaatste Ba Anansi, geholpen door zijn vrouw en kinderen, een grooten pot half vol water op vuur en wendde zich vervolgens tot Kesi-kesi. "Luister, Mat Kesi-kesi,» sprak hij. "Ik begeef mij in den pot en je maakt dezen dicht. Voorts ga je op het deksel zitten, waar je bij tusschenpoozen vraagt: "man bori?» Als ik lang genoeg in den pot geweest ben, zal ik antwoorden: "man bori.». Dan verwisselen wij van plaats en 
doe ik de vraag, die jij beantwoorden moet.» Hierna daalde Ba Anansi in den pot, dien hij ook door Mat Kesi-kesi liet toedekken.

Mat Kesi-kesi zette zich op 't deksel neer en vroeg verscheidene malen: "man bori?» Daarop riep Ba Anansi telkens uit: *fijn, heerlijk, overheerlijk!» tot het water warm werd. Toen antwoordde hij: "man bori.» Kesi-kesi sprong op den grond, liet $\mathrm{Ba}$ Anansi uit den pot en ging er zelf in.

Ba Anansi deed het deksel op den pot en belaadde het met zware steenen. Op deze nam hij plaats, vragende: "man bori?» Hij behoefde zijn vraag niet te herhalen, want Mat Kesi-kesi kreeg het al gauw te warm en gaf ten antwoord: "man bori." Instede van den pot voor hem te openen, sprak Ba Anansi spottend: nono man no bori, Mat Kesi-kesi, bika te wan man bori, hem tifi moes piri, hem tere moes kroroe (neen, man is niet gekookt, Mat Kesi-kesi want als een man gekookt is, moeten zijn tanden ontbloot zijn, moet zijn staart gekruld zijn).» Dit hoorende, trachtte Mat Kesi-kesi vergeefs het zwaar beladen deksel van den pot af te stooten, terwijl hij luidkeels begon te schreeuwen: «ja, ja, man bori, Ba Anansi, man bori!» Doch Ba Anansi hield vol, dat «te wan man bori, hem tifi moes piri, hem tere moes kroroe," tot Kesi-kesi's stem zwakker werd en geheel wegstierf. Toen klom hij van den pot af, opende dezen en haalde er den gekookten Kesi-kesi uit met diens ontbloote tanden en gekrulden staart.

Ba Anansi gaf Kesi-kesi's lichaam aan Sa Akoeba, die het schoonmaakte en met wat vet braadde. Dien dag vulden Anansi en zijn familie hun buikjes met heerlijk bruin gebraden apenvleesch, dus stierven zij niet van honger.

Bij gekookte apen zijn de tanden ontbloot en is de staart gekruld.

XXIV. Hoe Ba Tigri en Mat Koni-koni in boschdieren veranderden en Krabieta ( $Z$ us geit) tot een huisdier gemaakt werd.

Eer tien tien, Er heerschte een schaarschte van levensmiddelen en Mat Koni-koni vroeg Sa Krabieta: "wil je niet wat eten met mij loopen zoeken?» Sa Krabieta antwoordde hem bevestigend, waarna zij er met twee groote zakken op uit gingen. $\mathrm{Na}$ een eindje geloopen te hebben, kwamen zij op een grasvlakte, waar een huisje stond, aan hetwelk een plank ontbrak. Het ge- 
bouw behoorde aan Ba Tigri, die er voor de deur zat. $Z_{\mathrm{ij}}$ verzochten Tigri om bij hem te mogen blijven wonen, waarop hij sprak: "goed, maar jelui moeten mijn woning eerst van de ontbrekende plank voorzien.» Met behulp van Sa Krabieta zette Koni-koni vlug de plank voor 't huis, waarin beiden terstond hun intrek namen.

Ba Tigri en Mat Koni-koni zouden zich beurtelings op jacht begeven, terwijl Sa Krabieta thuis voor het eten zorgde of er ander werk deed. De geheele week ging Tigri jagen en doodde al Koni-koni's familieleden, eerst zijn neven en nichten, daarna zijn ooms en tantes, vervolgens zijn broers en zusters en ten slotte zijn vader en moeder. Mat Koni-koni at natuurlijk geen stuk toespijs en werd steeds droeviger. Toen Ba Tigri met Koni-koni's vermoorde ouders van de jacht thuis kwam, snelde deze naar buiten, waar hij in luid geween losbarstte. Ba Anansi ging er toevallig voorbij en vroeg hem deelnemend waarom hij zoo huilde. Daarop vertelde Koni-koni snikkend, wat er gebeurd was en Anansi sprak: "Treur niet langer, Mat Koni-koni. Ik zal je tegen betaling spoedig een $\mathrm{Tigri}$ obia (middel tegen tijgers) bezorgen, om je te wreken. Je besmeert er eenvoudig je achterlijf mee en keert dit dan toe aan de Tigri's. Als zij hierdoor niet onmiddellijk omkomen, behoef je er geen cent voor te geven. Ik ben geen bedrieger." Hij verwijderde zich haastig, om het negerkunstmiddel te bereiden.

Ba Anansi bracht des ochtends het Tigri obia voor Mat Koni-koni, welk middel uit een roodbruinen zalf bestond. Konikoni smeerde dit aan zijn achterlijf en ging eveneens een week lang iederen dag ter jacht. Het kunstmiddel werkte uitstekend, vermits al de Tigri's wien hij onverwacht zijn helder roodbruin gekleurd zitvlak toekeerde, morsdood neervielen. Op deze wijze doodde hij gemakkelijk Tigri's geheele familie en sleepte eindelijk ook diens ouders huiswaarts. Op het zien dezer lijken vluchtte Ba Tigri uit vrees voor den gevaarlijken Koni-koni naar 't bosch. Mat Konikoni vervolgde hem in de wildernis, tot beiden er in boschdieren veranderden. Daar zij niet wederkeerden, legde Ba Anansi, voor hetgeen hij van Koni-koni te goed had, beslag op het huis met Sa Krabieta erin, die tot een huisdier gemaakt werd.

Koni-koni's achterlijf bezit nog steeds de helder roodbruine kleur, doch heeft alle tooverkracht verloren. 